\title{
Article
}

\section{The Effect of Biopreparations and Biostimulants on the Chemical Composition and Microorganisms Associated with Verticillium Wilt of Horseradish Roots (Armoracia rusticana Gaertn.)}

\author{
Katarzyna Gleń-Karolczyk ${ }^{1, * \mathbb{D}}$, Elżbieta Boligłowa ${ }^{1}$, Agnieszka Filipiak-Florkiewicz ${ }^{2}$ (D) Adam Florkiewicz $^{3}$ \\ and Lidia Luty ${ }^{4}(\mathbb{D}$
}

Citation: Glen-Karolczyk, K.; Boligłowa, E.; Filipiak-Florkiewicz,

A.; Florkiewicz, A.; Luty, L. The Effect of Biopreparations and Biostimulants on the Chemical Composition and Microorganisms Associated with Verticillium Wilt of Horseradish Roots (Armoracia rusticana Gaertn.). Appl. Sci. 2021, 11, 680. https:// doi.org/10.3390/app11020680

Received: 24 November 2020 Accepted: 8 January 2021 Published: 12 January 2021

Publisher's Note: MDPI stays neutral with regard to jurisdictional clai$\mathrm{ms}$ in published maps and institutional affiliations.

Copyright: (C) 2021 by the authors. Licensee MDPI, Basel, Switzerland. This article is an open access article distributed under the terms and conditions of the Creative Commons Attribution (CC BY) license (https:// creativecommons.org/licenses/by/ $4.0 /)$.
1 Department of Microbiology and Biomonitoring, Faculty of Agriculture and Economics, University of Agriculture in Kraków, Mickiewicza 21, 31-120 Kraków, Poland; elzbieta.boliglowa@urk.edu.pl

2 Department of Plant Products Technology and Nutrition Hygiene, University of Agriculture in Kraków, 122 Balicka, 30-149 Kraków, Poland; agnieszka.filipiak-florkiewicz@urk.edu.pl

3 Department of Food Analysis and Quality Assessment, University of Agriculture in Kraków, 122 Balicka, 30-149 Kraków, Poland; adam.florkiewicz@urk.edu.pl

4 Department of Statistics and Econometrics, University of Agriculture in Kraków, Al. Mickiewicza 21, 31-120 Kraków, Poland; lidia.luty@urk.edu.pl

* Correspondence: katarzyna.glen-karolczyk@urk.edu.pl

Abstract: The basic foundation of plant production consists in plant protection treatments, which largely shape the quality of plant raw material intended for the food industry. Due to its long growing season, horseradish requires more treatments than average. Intensive protection based on synthetic pesticides favours the accumulation of their residues in plants and generates serious environmental problems. We have examined the effect of chemical protection and its reduced variant as well as three variants of biological protection, differentiated in terms of preparations used for seedlings treatment (Pythium oligandrum, Bacillus subtilis, and Ecklonia maxima), on the content of dry matter, protein, fat, carbohydrates, and the disease severity index (DSI) of Verticillium wilt of horseradish roots. The quantitative and qualitative changes in the microorganism communities associated with this disease were determined. Thirty-four species of fungi and Globisporangium irregulare have been shown to contribute to the pathogenesis of Verticillium wilt. The following were found with the highest frequency: Verticillium dahliae $(14.37 \%)$, G. irregulare $(6.87 \%)$, Ilyonectria destructans (6.73\%), Fusarium acuminatum (6.53\%), Rhisoctonia solani (6.75\%), Epicoccum nigrum (5.56\%), and Alternaria brassicae (5.36\%).We found that water deficit promotes the increase of DSI and reduces the number and richness of fungal species isolated from diseased roots. The variant of biological protection with treatment of seedlings of E. maxima extract and with reduced chemical protectionin dry seasons give the best protective effects. Under conditions of optimal water supply, biological protection (P. oligandrum) is more effective than chemical protection. Biological protection increases biodiversity in the population of microorganisms that contribute to blackening of the conductive bundles of horseradish roots. There is a significant negative correlation between the number of isolated microorganisms and the DSI value. Increasing the number of the CFUs is accompanied by a reduction in the symptoms of Verticillium wilt of horseradish roots. Biological protection in years with sufficient water supply results in a significant increase in the content of dry matter, protein, and carbohydrates in horseradish roots. Under the influence of protective treatments, the ash content in the roots and its alkalinity decrease.

Keywords: horseradish roots; Verticillium wilt of horseradish roots; Bacillus subtilis; Pythium oligandrum; Ecklonia maxima; chemical composition 


\section{Introduction}

Known in the past under a variety of names-Sinapi persicum, Raphanus vulgaris, Raphanus rusticanus, and Cochlearia armoracia-the horseradish (Armoracia rusticana Gaertn.) is a perennial plant belonging to the Brassicaceae family, native to the Mediterranean [1,2]. For centuries, it has been a valued medicinal plant, used as a condiment and known as a natural cosmetic and food preservative [3], even though it was introduced into cultivation as late as the end of the eighteenth century. Today, horseradish is grown commercially in all parts of the world. In Europe, the main production is concentrated in Hungary, Austria, Germany, and Poland [4], whereas the worldwide leadership in horseradish cultivation belongs to the United States, with over $50 \%$ of the plantations located in the state of Illinois [2,5]. In Poland, horseradish has been cultivated continuously since 1939, mostly in the south-western part of the Lodz region.

Due to their nutritional value, horseradish roots provide a valuable raw material for the food industry. They constitute a rich source of fibre, mineral salts, calcium, potassium, magnesium, sulphur, sodium, iron, zinc, phosphorus, iodine, vitamins $C, B_{1}, B_{2}$, provitamin $\mathrm{A}$, as well as flavonoids, sugars, enzymes, and amino acids [6-9]. In addition, they contain bioactive ingredients who serichness in glucosinolates (being a source of isothiocyanates that have a wide range of medical applications) is particularly appreciated $[10,11]$. Among others, isothiocyanates have bactericidal and anti-inflammatory properties, and they inhibit the development of colon, stomach, and lung cancer [12-15]. Horseradish peroxidase is used in clinical trials and immunological tests [16-18].

In light of the above, plantations must be managed to ensure the highest quality of the roots [19]. The food industry uses roots that are smooth, with light skin, free from defects such as cracks, deformations, or damage caused by pests, and last but not least, free from internal discoloration. Meanwhile, the lengthy period of this plant's vegetation certainly favours infection by pathogens and possible damage by insects $[2,20,21]$. It is estimated that during the growing season horseradish is attacked by about 22 species of pests, some of them occurring in several generations. In turn, the most common infectious diseases in horseradish plantations are white rust (Albugo candida), Cercospora leaf spot of crucifers (Cercospora armoraciae), Phoma leaf spot (Leptosphaeria maculans), Cylindrosporium disease (Cylindrosporium concentricum), and Alternaria Black spot (Alternaria brassicae, A.brassicicola, A.alternata) $[2,20,22-28]$. In all climate zones, an important pathogen limiting the yield and quality of horseradish roots is the genus Verticillium [21,28-32]. The dominant species is $V$. dahliae Kleb. In the United States, the latter is considered the main causeof internal discoloration of horseradish roots, and the disease itself is referred to as "internally discoloured horseradish roots" [28]. In Poland, however, this disease is known as Verticillium wilt (annular, or ring-shaped, blackening of horseradish roots).

The guarantee of maintaining good quality and high yields comes from, inter alia, controlling the severity of infectious diseases during the growing season. In the conventional cultivation system, synthetic fungicides are commonly used for seedling treatment and foliar application, although their effectiveness is not always satisfactory $[19,20]$. The negative effect of the use of chemical plant protection products is that, in addition to pests, they eliminate beneficial organisms from the environment, they decrease the soil biological activity, and may often cause resistance in pests [33,34]. A global problem is the loss of soil biodiversity, which, according to the latest reports, contributes to the health of plants, animals, and humans [35-39]. The restoration of biodiversity is the basis of ecological and integrated programs implemented as part of sustainable agricultural development. Organic fertilization is an essential factor in restoring the balance within ecosystems [40-43]. It has been proven that biostimulants also have a similar effect. Brown algae extracts restore the relative balance in the soil-the balance between groups of parasitic, saprotrophic, and antagonistic microorganisms-which contributes to betterplant health [44]. Thus, thanks to brown algae, the use of synthetic fungicides against Botrytis cinerea can be reduced by as much as $80 \%$ [45]. 
What is more, replacing chemical protection with biological preparations makes it possible to avoid negative consequences for the environment and ecology. In the fight against pathogens, non-pathogenic bacteria are used: Bacillus subtilis strain QST 713, Bacillus thuringiensis subsp. israelensis (serotype H-2014) strain AM65-52, Pseudomonas chlororaphis strain MA342, Streptomyces griseoviridis K61, as well as fungi: Trichoderma, Gliocladium, Fusarium, and Oomycetes-Pythium oligandrum strainM1, [46-50]. A small number of studies conducted on other plant species show that biological control agents (BCAs) and natural biostimulants or plant growth promoters (PGPs) significantly modify the content of nutrients and bioactive substances in plant raw materials [51,52].

So far, it has not been investigated whether and to what extent biological protection treatments, and the inclusion of biopreparations and biostimulants to reduce the amount of synthetic pesticides used, translate into variability in the communities of microorganisms associated with Verticillium wilt of horseradish roots. This gap is filled by the study presented in this paper, undertaken with the following objectives: (I) to understand the communities of microorganisms associated with Verticillium wilt of horseradish roots; (II) to assess the impact of protective measures on the quantitative and qualitative composition of the communities of microorganisms participating in the epidemiology of this disease; (III) to assess the relationship between the number of these communities and the intensity of Verticillium wilt of horseradish roots; (IV) to determine the optimal protective treatments that would allow horseradish roots with the best quality and nutritional value indicators to be obtained. Therefore, in the present study, we have performed a comparative assessment of chemical protection, its reduced variant and three variants of biological protection with the participation of BCAs (Pythium oligandrum oospores and Bacillus subtilis) and PGPs (Ecklonia maxima extract and a mixture of three nitrophenolic compounds), for the content of dry matter, protein, fat, carbohydrates, and ash in horseradish roots.

\section{Materials and Methods}

\subsection{Plant Material and Design of the Field Experiment}

The study material consisted of roots of horseradish (Armoracia rusticana Gaertn.) of the Polish variety Alpo that were collected annually in the third decade of October from a field experiment carried out in 2015-2017 in Siemkowice $\left(51^{\circ} 12.1164^{\prime} \mathrm{N} ; 18^{\circ} 53.928^{\prime} \mathrm{E}\right)$ in the Łódź region of Poland.

The field experiment was carried out on podzolic soil composed of light, highly sandy clay with a fine sand grain size composition, classified as $\mathrm{IVb}$, with good rye agricultural suitability complex $[53,54]$. The soil was acidic $(\mathrm{pH}=5.79)$ and had low humus content $(1.57 \%)$. The topsoil was rich in potassium, but there were deficiencies of other macroelements and micronutrients such as $\mathrm{Cu}, \mathrm{Zn}$, and $\mathrm{B}$, as well as excessive iron content. The content of heavy metals did not exceed the permissible standards.

A single-factor experiment was established using the randomized block method in four replications. This design provided six combinations of plant protection (24 plots in total). The size of the plot for observation and harvest was $20 \mathrm{~m}^{2}$ (total working area of $480 \mathrm{~m}^{2}$ ). Each year, the forecrop for horseradish was spring barley. For winter ploughing, a full dose of cattle manure of $35 \mathrm{t} \cdot \mathrm{ha}^{-1}$ and mineral fertilizers were brought in, in doses determined based on plant requirements and soil analyses for the content of available forms of the nutrients. In autumn, $400 \mathrm{~kg} \cdot \mathrm{ha}^{-1}$ of triple granular superphosphate $\left(46 \% \mathrm{P}_{2} \mathrm{O}_{5}\right)$ and $300 \mathrm{~kg} \cdot \mathrm{ha}^{-1}$ of potassium salt $\left(60 \% \mathrm{~K}_{2} \mathrm{O}\right)$ were used. In spring, $150 \mathrm{~kg} \cdot \mathrm{ha}^{-1}$ of Polidap NP (S) fertilizer $\left(18 \% \mathrm{~N}, 46 \% \mathrm{P}_{2} \mathrm{O}_{5}, 5 \% \mathrm{SO}_{3}\right)$ was sown, and at the end of June, calcium nitrate with boron was added $(15.4 \% \mathrm{~N}, 19 \% \mathrm{Ca}, 0.3 \% \mathrm{~B})$ in the amount of $200 \mathrm{~kg} \cdot \mathrm{ha}^{-1}$. The deficiencies of copper, zinc, and boron were also supplemented by introducing $60 \mathrm{~kg} \cdot \mathrm{ha}^{-1}$ copper sulphate, $40 \mathrm{~kg} \cdot \mathrm{ha}^{-1}$ zinc sulphate, and $10 \mathrm{~kg} \cdot \mathrm{ha}^{-1}$ borax. Horseradish seedlings, 30-35 cm long, were planted in the second decade of March, in rows with a spacing of $62.5 \mathrm{~cm} \times 30 \mathrm{~cm}$ (planting density of 80 thousand seedlings per ha ${ }^{-1}$ ). 


\subsection{Protection Treatments}

The research factor was protection against infectious diseases, which included horseradish seedling treatment before planting and foliar application of preparations.Due to the high risk of insect infestation, it was also necessary to activate pest control. During the growing season, the horseradish was protected according to the scheme presented in Table 1 . The control of weeds throughout the entire experiment was conducted mechanically. The following agents were used in the experiment: chemical, biological, as well as biostimulants included in the list below.

Table 1. Scheme of horseradish protection treatments.

\begin{tabular}{|c|c|c|c|c|}
\hline \multirow{3}{*}{ Treatments } & \multicolumn{4}{|c|}{ Protection Method } \\
\hline & \multirow{2}{*}{$\begin{array}{l}\text { Root Cuttings } \\
\text { Treatment } \\
\text { Before Planting }\end{array}$} & \multicolumn{3}{|c|}{ TheFoliar Application } \\
\hline & & $\begin{array}{l}\text { Fungicide } \\
\text { Preparations }\end{array}$ & $\begin{array}{c}\text { Insecticide } \\
\text { Preparations }\end{array}$ & Biostimulants \\
\hline Control & Untreated & Without protection & $\begin{array}{c}1 \times \text { Decis Mega } 50 \text { EW, } \\
0.151 \cdot \mathrm{ha}^{-1} \\
1 \times \text { Proteus } 110 \text { OD, } \\
0.61 \cdot \mathrm{ha}^{-1} \\
1 \times \text { Sumi Alpha } 050 \mathrm{EC}, \text {. } 21 \cdot \mathrm{ha}^{-1} \\
4 \times \mathrm{Dipel}^{\circledR} \\
\text { WG, } 1{\mathrm{~kg} \cdot \mathrm{ha}^{-1}}^{-1}\end{array}$ & Not used \\
\hline
\end{tabular}

Chemical protection

\begin{tabular}{|c|c|c|c|c|}
\hline \multirow[t]{2}{*}{$\mathrm{ChP}$} & \multirow[t]{2}{*}{$\begin{array}{c}\text { Topsin M } 500 \text { SC } \\
0.2 \% \text { solution) (soaking } \\
\text { for } 15 \mathrm{~min} .)\end{array}$} & $\begin{array}{c}2 \times \text { Dithane Neo Tec } \\
75 \text { WG, } 2 \mathrm{~kg} \cdot \mathrm{ha}^{-1} \\
2 \times \text { Amistar Opti } \\
480 \mathrm{SC}, 2.5 \mathrm{l} \cdot \mathrm{ha}^{-1} \\
2 \times \text { Ridomil Gold MZ } \\
\text { Pepite } 67.8 \mathrm{WG} \\
2 \mathrm{~kg} \cdot \mathrm{ha}^{-1}\end{array}$ & 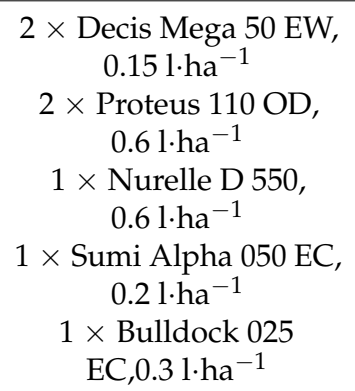 & Not used \\
\hline & & \multicolumn{3}{|c|}{$\begin{array}{l}\text { First treatments in the first pair of leaves unfolded. Next treatments depending on the } \\
\text { occurrence of disease symptoms and pests. The preparations were used alternately. }\end{array}$} \\
\hline \multicolumn{5}{|c|}{ Reduced chemical protection with the participation of biopreparations and biostimulants } \\
\hline \multirow[t]{2}{*}{$\mathrm{RChP}$} & \multirow{2}{*}{$\begin{array}{l}\text { Topsin M } 500 \text { SC } \\
(0.2 \% \text { solution }) \\
\text { (soaking } \\
\text { for } 15 \mathrm{~min} .)\end{array}$} & $\begin{array}{c}1 \times \text { Amistar Opti } \\
480 \text { SC, } 2.5 \mathrm{l} \cdot \mathrm{ha}^{-1} \\
1 \times \text { Polyversum WP } \\
200 \mathrm{~g} \cdot \mathrm{ha}^{-1} \\
1 \times \text { Serenade ASO } \\
8 \mathrm{l} \cdot \mathrm{ha}^{-1}\end{array}$ & 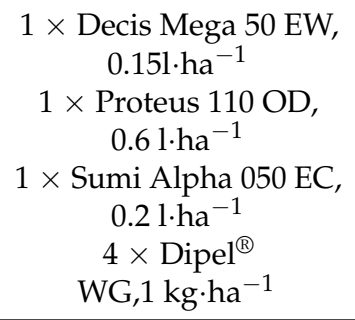 & \multirow{2}{*}{$\begin{array}{c}2 \times \text { Kelpak SL, } \\
41 \cdot \text { ha }^{-1} \\
\text { (first treatment in the } 4 \text {-leaf stage, } \\
\text { the next in the 9- leaf stage) } \\
1 \times \text { Asahi SL, } \\
0.51 \cdot \text { ha }^{-1} \\
\text { (when leaves cover } 40 \% \text { of } \\
\text { the soil) }\end{array}$} \\
\hline & & $\begin{array}{r}\text { First treatment in the } \\
\text { leaves. Next treatn } \\
\text { occurrence of disease } \\
\text { preparations were used } \\
\text { with biopreparations st } \\
\text { the growing season, at } \\
\text { of chemical prepa } \\
\text { adjuvant-300 mL h } \\
\text { with biop }\end{array}$ & $\begin{array}{l}\text { tage of the first pair of } \\
\text { nt depending on the } \\
\text { mptoms and pests. The } \\
\text { lternately. The protection } \\
\text { ted in the second half of } \\
\text { ast } 10 \text { days after the use } \\
\text { tions. The Protector } \\
\text { - _ was used together } \\
\text { eparations. }\end{array}$ & \\
\hline
\end{tabular}


Table 1. Cont.

\begin{tabular}{|c|c|c|c|c|}
\hline \multirow{3}{*}{ Treatments } & \multicolumn{4}{|c|}{ Protection Method } \\
\hline & \multirow{2}{*}{$\begin{array}{l}\text { Root Cuttings } \\
\text { Treatment } \\
\text { Before Planting }\end{array}$} & \multicolumn{3}{|c|}{ TheFoliar Application } \\
\hline & & $\begin{array}{c}\text { Fungicide } \\
\text { Preparations }\end{array}$ & $\begin{array}{l}\text { Insecticide } \\
\text { Preparations }\end{array}$ & Biostimulants \\
\hline \multicolumn{5}{|c|}{ Biological protection } \\
\hline ВРPo & $\begin{array}{l}\text { Polyversum WP, } 10 \mathrm{~g} \\
\mathrm{~kg}^{-1} \text { of cuttings } \\
\text { (soaking for } 30 \mathrm{~min} . \text { ) }\end{array}$ & \multirow{3}{*}{$\begin{array}{c}2 \times \text { Polyversum WP }_{200 \mathrm{~g} \cdot \mathrm{ha}^{-1}} \\
2 \times \text { Serenade ASO } \\
8 \mathrm{l} \cdot \mathrm{ha}^{-1}\end{array}$} & \multirow{3}{*}{$\begin{array}{c}5 \times \text { Dipel }^{\circledR} \text { WG, } \\
1 \mathrm{~kg} \cdot \mathrm{ha}^{-1} \\
3 \times \text { Spin Tor } 240 \mathrm{SC} \\
0.4 \mathrm{l} \cdot \mathrm{ha}^{-1}\end{array}$} & \multirow{3}{*}{$\begin{array}{c}2 \times \text { Kelpak SL, } \\
41 \cdot \text { ha }^{-1} \\
\text { (first treatment in the 4-leaf } \\
\text { stage, the next in the } 9 \text { - leafstage) } \\
2 \times \text { Asahi SL, } \\
0.51 \cdot \text { ha }^{-1} \\
\text { (when leaves cover } 40 \% \text { of the } \\
\text { soil, the next at the beginning } \\
\text { of August }\end{array}$} \\
\hline BPBs & $\begin{array}{c}\text { Serenade ASO, } 400 \mathrm{~mL} \\
\mathrm{~kg}^{-1} \text { of cuttings } \\
\text { (soaking for } 30 \mathrm{~min} . \text { ) }\end{array}$ & & & \\
\hline BPEm & $\begin{array}{c}\text { Kelpak SL, } 0.4 \% \\
\text { (soaking for } 10 \mathrm{~min} . \text { ) }\end{array}$ & & & \\
\hline
\end{tabular}

Dates oftreatments depending on the occurrence of disease symptoms and pests, were made alternately.

Horseradish root cuttings were manually treated with Polyversum WP, Serenade ASO, Kelpak SL and Topsin M 500 SC. The plants were sprayed with a hand sprayer (Titan 12 knapsack sprayer, Marolex).

Fungicides: Topsin M 500 SC-Thiophanate-methyl—500 g.1 ${ }^{-1}$ (Nippon Soda Co. Ltd., Tokyo, Japan); Dithane Neo Tec 75 WG-Mancozeb: a complex of zinc with polymeric manganese ethylene bis (dithiocarbamate), $20 \%$ manganese and $2.5 \%$ zinc $-750 \mathrm{~g} \cdot \mathrm{kg}^{-1}$ (Endophile Industries Limited, Mumbai, Republic of India); Amistar Opti 480 SC—chlorothalonil— 400 g. $1^{-1}$, azoxystrobin $-80 \mathrm{~g} \cdot \mathrm{l}^{-1}$ (Syngenta Limited, Great Britain and Northern Ireland); Ridomil Gold MZ Pepite $67.8 \mathrm{WG}$-metalaxyl-M-38.8 $\mathrm{g} \cdot \mathrm{kg}^{-1}$, mancozeb—640 $\mathrm{g} \cdot \mathrm{kg}^{-1}$ (Syngenta Polska Sp.z o.o., Warsaw, Poland).

Insecticides: Nurelle D 550 WG—chlorpyrifos— $550 \mathrm{~g} \cdot \mathrm{1}^{-1}$; cypermethrin $50 \mathrm{~g} \cdot \mathrm{l}^{-1}$ (Arysta Life Science Polska Sp. z o.o., Warsaw, Poland); Decis Mega 50 EW—deltamethrin 50 g. $1^{-1}$ (Bayer SAS, Lyon, France); Proteus 110 OD—thiacloprid-100 g. $\mathrm{l}^{-1}$, deltamethrin-10 g. $\mathrm{l}^{-1}$ (Bayer Sp.z o.o., Warsaw, Poland); Sumi-Alpha 050 EC—esfenvalerate- $50 \mathrm{~g} \cdot \mathrm{l}^{-1}$ (Arysta LifeScience Polska Sp.z o.o., Warsaw, Poland); Bulldock 025 EC—beta-cyfluthrin—25 g.1 $1^{-1}$ (Nufarm Polska Sp.z o.o., Warsaw, Poland).

Biological control agents (BCAs): Polyversum WP-106 Pythium oligandrum oospores per $1 \mathrm{~g}$ of the agent (Biopreparaty Ltd., Uherce, Czech Republic); Serenade ASO-Bacillus subtillis str. QST 713-13.96 g. $1^{-1}$ (minimum concentration 1.042.1012 CFU $\cdot 1^{-1}$ ) (Bayer AG, Leverkusen, Germany); Dipel ${ }^{\circledR}$ WG-Bacillus thuringiensis var. kurstaki p. ABTS $351-540 \mathrm{~g} \cdot \mathrm{kg}^{-1}$ (Sumitomo Chemical Agro Europe S.A.S., French Republic).

Biotechnological plant protection product: SpinTor 240 SC—-spinosad: Spinozyn A, Spinozyn D (a substance from the group of macrocyclic lactones) $-240 \mathrm{~g} \cdot \mathrm{l}^{-1}$ (Dow AgroSciences Polska Sp.z o.o., Warsaw, Poland).

Biostimulants (PGPs): Kelpak SL-auxins- $11.0 \mathrm{mg} \cdot \mathrm{l}^{-1}$ and cytokinins- $0.031 \mathrm{mg} \cdot \mathrm{l}^{-1}$ obtained from Ecklonia maxima algae (Kelp Products International (Pty) Ltd., Simon's Town, South Africa); Asahi SL—nitrophenols naturally occurring in plants—sodium paranitrophenolate $-3 \mathrm{~g} \cdot \mathrm{l}^{-1}$, sodium ortho-nitrophenolate $-2 \mathrm{~g} \cdot \mathrm{l}^{-1}$, sodium 5 -nitroguajacolate $-1 \mathrm{~g} \cdot \mathrm{l}^{-1}$ (ArystaLifeScience Ltd., Praha, Czech Republic).

\subsection{Assessment of the Prevalence of Verticillium Wilt of Horseradish Roots}

Horseradish roots were harvested in the third decade of October. Fifty pieces of main roots were taken from each plot, they were washed under running water, and the percentage of roots showing the symptoms of Verticillium wilt of horseradish roots was assessed. For this purpose, the roots were cut crosswise at a distance of $4 \mathrm{~cm}$ from the rosette (crown of the root). As there isno approved scale for the infection assessment for 
horseradish roots, analogous to the EPPO standard PP 1/78 (3), a four-point scale of the percentage infestation of the surface of vascular bundles in the cross-section was adopted.

According to thatscale, 0 - signifies no disease symptoms, 1 - signifies $1 \%-25 \%$ of the area of the ring of vascular bundles in a discolouredroot, $2-(26 \%-50 \%)$, and 3- $(51 \%-100 \%)$, respectively.

The severity of the disease was expressed by the disease severity index (DSI) index (\%), calculated according to the Townsend and Heuberger formula [55]:

$$
\mathrm{DSI} \%=\frac{\sum_{0}^{i}(n \cdot v)}{i \cdot N} \cdot 100
$$

where DSI-disease severity index; $n$-number of plants at a given degree of infestation; $v$-degree of infestation, $i$ - the highest degree of infestation; $N$-total number of analysed plants.

\subsection{Isolating and Identifying the Fungi from the Roots Infected Internally}

The main roots of horseradish with visible internal discoloration of the vascular bundles were included in the mycological analysis. The material for isolation was collected immediately after health assessment. In accordance with the adopted phytopathological procedure, 30 roots with the strongest symptoms of Verticillium wilt of horseradish roots and with even thickness (diameter approx. $2 \mathrm{~cm}$ ) were taken from each combination. The root was cut lengthwise, and then one 1-milimeter-thick half-slice (disc) was cut transversely, thus obtaining a total of 60 half-discs. Sections 2 and $3 \mathrm{~mm}$ in size were cut from the border of healthy and diseased tissue. From each combination of sections, 200 were prepared, which weighed $5 \mathrm{~g}$. Then, they were disinfected for $30 \mathrm{~s}$ in $0.5 \%$ sodium hypochlorite (Javal, Warszawa, Poland). The root fragments were rinsed three times for $10 \mathrm{~min}$ in sterile distilled water and thoroughly dried on sterile gauze. Then, 10 pieces at a time, they were placed on solidified PDA (potato dextrose agar) medium with $0.05 \mathrm{~g} \cdot \mathrm{1}^{-1}$ chloramphenicol and pH 6.5 in Petri dishes with a diameter of $150 \mathrm{~mm}$. The fungi were grown in an air-conditioned chamber for up to 10 days, at a temperature of $23{ }^{\circ} \mathrm{C}$ and a 12-h light cycle. The number of obtained isolates was counted, which corresponded to the number of colony forming units (CFU) per $5 \mathrm{~g}$ of diseased horseradish roots. The fungal cultures were transported onto PDA and water agar (WA) medium. The filamentous fungi were identified using the MALDI-TOF MS technique (matrix assisted laser desorption/ionization time-of-flight mass spectrometry), which uses mass spectroscopy to determine ribosome protein profiles. Reference spectra for these are stored in the library database of Bruker Daltonik GmbH [56].

The cultivation and sample preparation of the filamentous fungi was performed according to the standard operating procedure developed by BrukerDaltonik GmbH. Tubes of $8 \mathrm{~mL}$ Modified Fluid Medium cat. no. 221014 (Becton Dickinson) were inoculated with a small amount of three-day-old fungal hyphae and sealed with a lid. They were then placed in an SB2 rotator (cat. no. Y552, Carl Roth GmbH \& Co KG) and incubated in the top mix until sufficient biological material was acquired. A detailed methodology for obtaining supernatants (crude protein extract) from the fungi is presented in the work of Gleń-Karolczyk et al. [42].

Then, $1 \mu \mathrm{L}$ of supernatant was pipetted onto a steel MALDI plate and allowed to dry at room temperature. Subsequently, $1 \mu \mathrm{L}$ of the alpha-cyano-4-hydroxycinnamic acid solution-HCCA matrix (cat. no. 8255344) — was applied and allowed to dry at room temperature. The plate was inserted into a MALDI Biotyper microflex apparatus, linked via computer to a database of reference spectra for fungi contained in Filamentous Fungi Library 1.0 (BrukerDaltonik $\mathrm{GmbH}$ ). The spot on the plate where the strains had beenlocated was marked, given a number, and the identification was started via the "start" table. Fungi identification was conducted using MBT Compass research use only (RUO) 4.1.60 software. Each isolate was identified twice. 


\subsection{Chemical Analyses}

Material for chemical analysis was collected from the parts of the roots on which the health assessment was performed. The content of dry matter was determined using gravimetric methods according to standard PN-ISO 712:2002 and expressed in g per $100 \mathrm{~g}$; the content of protein was determined using the Dumas method (TruSpec, Leco) according to PN-EN ISO 16634-1:2008 (nitrogen to protein conversion factors: 5.9); fat content, by extraction method in overcritical $\mathrm{CO}_{2}$ state (TFE 2000, Leco); ash content, by burning in a muffle furnace (Nabertherm model LE6/11/B150) according to PN-ISO 2171:1994; alkalinity of ash was determined according to PN-A-75101/08: 1990 (expressed in ml of $0.1 \mathrm{M} \mathrm{HCl}$ per $100 \mathrm{~g}$ dry matter of sample).

The accuracy of methods used was verified on the basis of certified reference material NCS ZC73012 - GSB-5. All the methods used were fully validated and checked using internal quality control procedures.

The amount of carbohydrates was calculated according to Kunachowicz et al. [57].

\subsection{Developing the Results}

\subsubsection{Descriptive Statistics}

The microorganisms colonizing the infected roots in particular combinations of the experiment were characterized using the following population parameters:

The frequency of occurrence of particular species $C=a / b \cdot 100 \%$

where: $a$-the number of occurrences of a given species; $b$ - the number of all isolates (100\%).

Based on the above, the fungi were assigned to frequency groups: eudominantsabove $10.0 \%$ of the total isolated fungi; dominants- $5.1-10.0 \%$; subdominants $-2.1-5.0 \%$; recedents-1.1-2.0\%; and subreferences below 1.0\% [58]. Moreover, the species richness index (S), which represents the total number of species in the sample, was used [59].

\subsubsection{Statistical Analysis}

Using a Statistica 13.1 PL software package, the results concerning the occurrence of Verticillium wilt of horseradish roots were subjected to a two-way ANOVA analysis (factor I being the year of cultivation and factor II the protection treatment). Homogeneous groups were determined using Tukey's test, and the significance level was assumed to be 0.05 . To determine the relationship between the intensity of Verticillium wilt of horseradish root (DSI) and the number of colony forming units (CFU) per $5 \mathrm{~g}$ of infected roots or the annual sum of precipitation (SP), Pearson correlation coefficients $(r)$ and regression equations were used. The correlation analysis was also used to determine the relationship between the prevalence of dominant species in communities of microorganisms isolated from horseradish roots.

On the other hand, the results concerning the chemical composition were presented as the mean value $\pm \mathrm{SD}$. They were subjected to a two-way ANOVA analysis. Duncan's post hoc test was applied. Differences were considered significant at $p<0.05$. The calculations were performed with the statistical software package Statistica 9.1 (StatSoft Inc., Tulsa, OK, USA).

\section{Results and Discussions}

\subsection{Verticillium Wilt of Horseradish Roots Depending on the Studied Factors}

Root diseases, in contrast to those occurring on leaves, directly affect the commercial value of horseradish, therefore, they pose a greater problem for agricultural producers. Fruit and vegetable processing plants, which in $90 \%$ are direct recipients of raw material from farmers, set requirements regarding horseradish root quality. Roots intended for the food industry should have smooth, light skin, and they should be free from defects such as cracks, deformation, or damage caused by pests, and internal discoloration is not tolerated either. 
A three-year study showed that horseradish cultivation in Poland is endangered by Verticillium wilt of horseradish roots. The intensity of this disease depends significantly on the conditions prevalent in a given growing year or season.

Weather conditions in the years of the study were varied (Table 2). They are described using the Sielianinov $(K)$ hydrothermal index:

$$
K=\frac{p}{0,1 \cdot \sum t}
$$

where: $p$-precipitation total for the examined period $(\mathrm{mm}) ; t$-mean daily air temperature $\left({ }^{\circ} \mathrm{C}\right)$.

Table 2. Precipitation totals and mean air temperatures at $2 \mathrm{~m}$ above sea level, in the growing months in the years 2015-2017, in the Siemkowice region (according to the Institute of Meteorology and Water Management National Research Institute in Poznań).

\begin{tabular}{|c|c|c|c|c|c|c|c|c|c|}
\hline \multirow{2}{*}{ Year } & \multicolumn{8}{|c|}{ Months } & \multirow{2}{*}{ Total/Mean } \\
\hline & III & IV & $\mathbf{V}$ & VI & VII & VIII & IX & $\mathbf{X}$ & \\
\hline \multicolumn{10}{|c|}{ Precipitation total [mm] } \\
\hline 2015 & 29.7 & 21.7 & 29.4 & 76.5 & 42 & 35.7 & 41.1 & 35.8 & 311.9 \\
\hline 2016 & 35.2 & 38.3 & 64.9 & 71.5 & 133.7 & 27.5 & 22.7 & 99.9 & 493.7 \\
\hline 2017 & 50.4 & 58.4 & 56.4 & 128.8 & 61.1 & 53.5 & 185.4 & 88.7 & 682.7 \\
\hline $1971-2010$ & 32.6 & 38.1 & 53.8 & 70.8 & 82.5 & 66.2 & 51.3 & 39.3 & 434.6 \\
\hline \multicolumn{10}{|c|}{ Mean air temperature $\left[{ }^{\circ} \mathrm{C}\right]$} \\
\hline 2015 & 5.1 & 8.4 & 13.2 & 16.7 & 20.1 & 22.8 & 15.4 & 7.5 & 13.7 \\
\hline 2016 & 4.0 & 8.7 & 14.7 & 18.4 & 18.9 & 18.0 & 16.0 & 7.7 & 13.3 \\
\hline 2017 & 5.9 & 7.1 & 13.4 & 17.1 & 18.1 & 19.3 & 13.4 & 10.1 & 13.1 \\
\hline $1971-2010$ & 2.9 & 7.7 & 13.3 & 16.0 & 17.7 & 17.5 & 13.0 & 8.3 & 12.1 \\
\hline \multicolumn{10}{|c|}{ Sielianinov hydrothermal coefficient [K] } \\
\hline 2015 & & $0.9 *$ & 0.7 & 1.5 & 0.7 & 0.5 & 0.9 & 1.5 & \\
\hline 2016 & & 1.5 & 1.4 & 1.3 & 2.3 & 0.5 & 0.5 & 4.2 & \\
\hline 2017 & & 2.7 & 1.4 & 2.5 & 1.1 & 0.9 & 4.6 & 2.8 & \\
\hline
\end{tabular}

${ }^{*} \mathrm{~K} \leq 0.4$-extremely dry month; $0.4<\mathrm{K} \leq 0.7$-very dry; $0.7<\mathrm{K} \leq 1.0$-dry; $1.0<\mathrm{K} \leq 1.3$-quite dry; $1.3<\mathrm{K} \leq 1.6$-optimal; $1.6<\mathrm{K} \leq 2.0$ moderately humid; $2.0<\mathrm{K} \leq 2.5$-humid; $2.5<\mathrm{K} \leq 3.0$-very humid; $\mathrm{K}>3.0$-extremely humid [60].

Of the seasons covered by the study, 2015 was the driest year (see Table 2). As little as $311.9 \mathrm{~mm}$ of rainfall was recorded from March to October. In the first growing season (April-June), precipitation totaled $127.6 \mathrm{~mm}$, and in the second (July-September), it amounted to $118.8 \mathrm{~mm}$. In turn, the year 2016 can be considered optimal in terms of water supply ( $493.7 \mathrm{~mm}$ ) and covering the needs of horseradish plants. However, after a very humid July, there was a significant deficit of rainfall in August and September, followed by excess precipitation in October. The study period from March to October 2017 was humid (682.7 $\mathrm{mm}$ of precipitation) and warm. In the period April-June, total precipitation was $243.6 \mathrm{~mm}$, and in July-September, it totaled $300.0 \mathrm{~mm}$. This means that the horseradish plants were sufficiently supplied with moisture.

The organisms responsible for the development of Verticillium wilt attack the roots with more intensity during drought periods, while the temperature seems to be a factor of lesser importance. The total precipitation of $682.7 \mathrm{~mm}$ in 2017 resulted in a significant reduction of discoloration within the vascular bundles (Figure 1). In turn, a decrease in the amount of precipitation by $189 \mathrm{~mm}$ in 2016 resulted in a significant increase in the disease severity index (DSI). On the other hand, the significant water deficit $(311.9 \mathrm{~mm})$ in the first year of the study contributed to the increase in the DSI. As the disease symptoms intensify, darkening of the tissues of the core (on the inside) and the cortex (on the outside) is observed. Internal discoloration of the roots significantly reduces the commercial yield, often completely (100\%) disqualifying them from being used for processing [32]. 


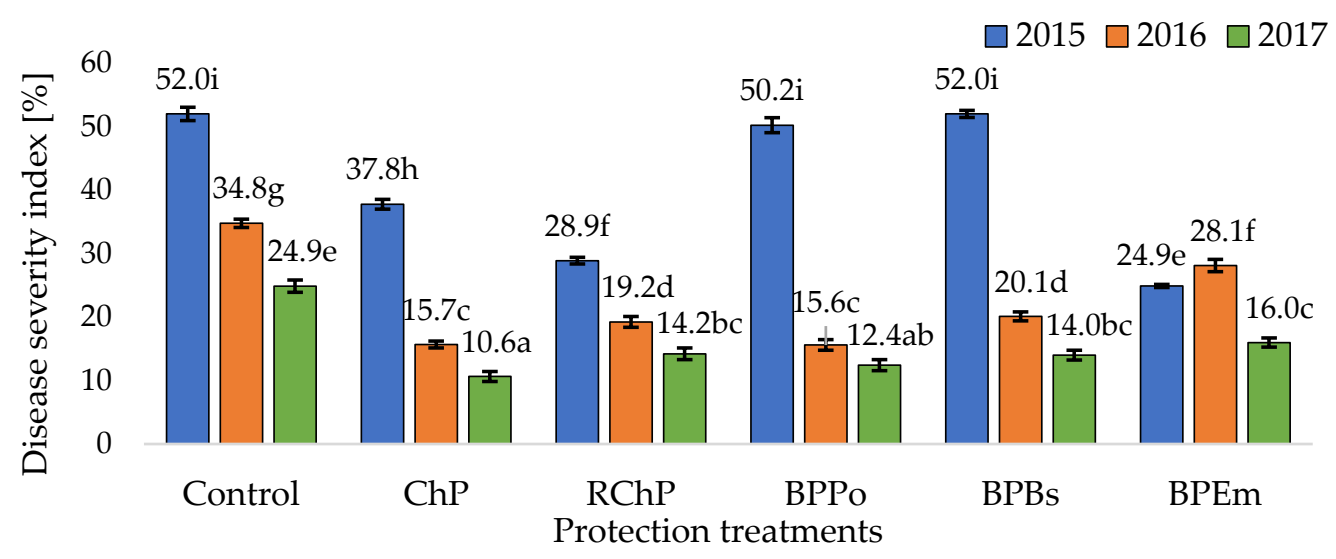

Figure 1. Infection of horseradish roots by a fungi complex causing Verticillium wilt. Disease severity index (DSI) [\%] (homogeneous groups, Tukey's HSD test, $\alpha=0.05$ ). Values marked with the same letters do not differ statistically significantly, $p<0.05$. Control-Without protection; $\mathrm{ChP}-\mathrm{Chemical}$ protection; RChP-Reduced chemical protection with the participation of biopreparations and biostimulants; BPPo-Biological protection (root cuttings treatment before planting with Pythium oligandrum); BPBs-Biological protection (root cuttings treatment before planting with Bacillus subtilis); BPEm-Biological protection (root cuttings treatment before planting with Ecklonia maxima).

In the opinion of Babadoost et al. [31], insufficient information on the etiology of this disease is the main reason for the lack of effective preparations to combat it. Although seedling treatment appears to be the first and best choice when it comes to protection against soil pathogens, there is also a marked lack of research in this field in the literature on the subject.

The weather conditions in the growing season strongly determined the severity of the disease and the effectiveness of the protection treatments. The interaction between the years and protection treatments turned out to be significant (Figure 1).

It was demonstrated that in the growing season (2017) with generally the lowest DSI, the applied protection treatments, except for BPEm, protected the horseradish roots against Verticillium wilt to equal extent. On the other hand, in 2015, a year characterized as dry and warm, the most intensive development of the disease was recorded, whereas there was no protective activity in BPBs and BPPo plots. In particular, it was the water deficit, persisting after planting horseradish seedlings and for the next two months, that contributed to this (Table 2). In the conditions of soil drought, the BCA (B. subtilis and P. oligandrum) did not protect the roots against pathogens causing Verticillium wilt of internal roots. The study showed that in such conditions, the best protective effect against Verticillium wilt of horseradish roots was achieved in the BPEm plot, where seedling treatment with E. maxima extract was supported by additional foliar application of biostimulants and biopreparations (Figure 1). It is worth noting that in 2015 also the option of protecting with a reduced amount of chemicals $(\mathrm{RChP})$ protected against Verticillium wilt of horseradish roots significantly more effectively than the $\mathrm{ChP}$. Therefore, in horseradish cultivation, there is a chance to minimize the number of treatments performed with synthetic fungicides without reducing the effectiveness of root protection. Glen-Karolczyk [61] points out that periods of extreme drought have become a dire problem for horseradish growers in Poland in recent years. Thus, it is reasonable to use the E. maxima-based biostimulant for horseradish seedling treatment and foliar application. The auxins and cytokines contained therein alleviate the stress associated with water deficit and promote the health of the roots [60]. In vitro studies also confirm the fungistatic effect of this biostimulant [21].

\subsection{Microorganisms Related to Verticillium Wilt of Horseradish Roots}

3.2.1. Quantitative Analysis of Microorganisms Colonizing Horseradish Roots Affected by Verticillium Wilt

The number of isolates obtained from internally infected horseradish roots varied according to the growing seasons. In the first year of the study (2015), the most intensive 
development of Verticillium wilt of horseradish roots (Figure 1) was represented by the smallest number of isolated microorganisms (Figure 2). In the following years (which were wetter), with lesser disease severity, the number increased. As the material collected for microbiological analysis was carefully weighed and cut into small pieces, it can be concluded that the number of isolates obtained corresponded to the number of colonyforming units (CFU) per $5 \mathrm{~g}$ of a diseased root. In this approach, on average, the highest amount of CFU in $5 \mathrm{~g}$ was found in infected roots from the 2017 growing season and the lowest in those from 2015.

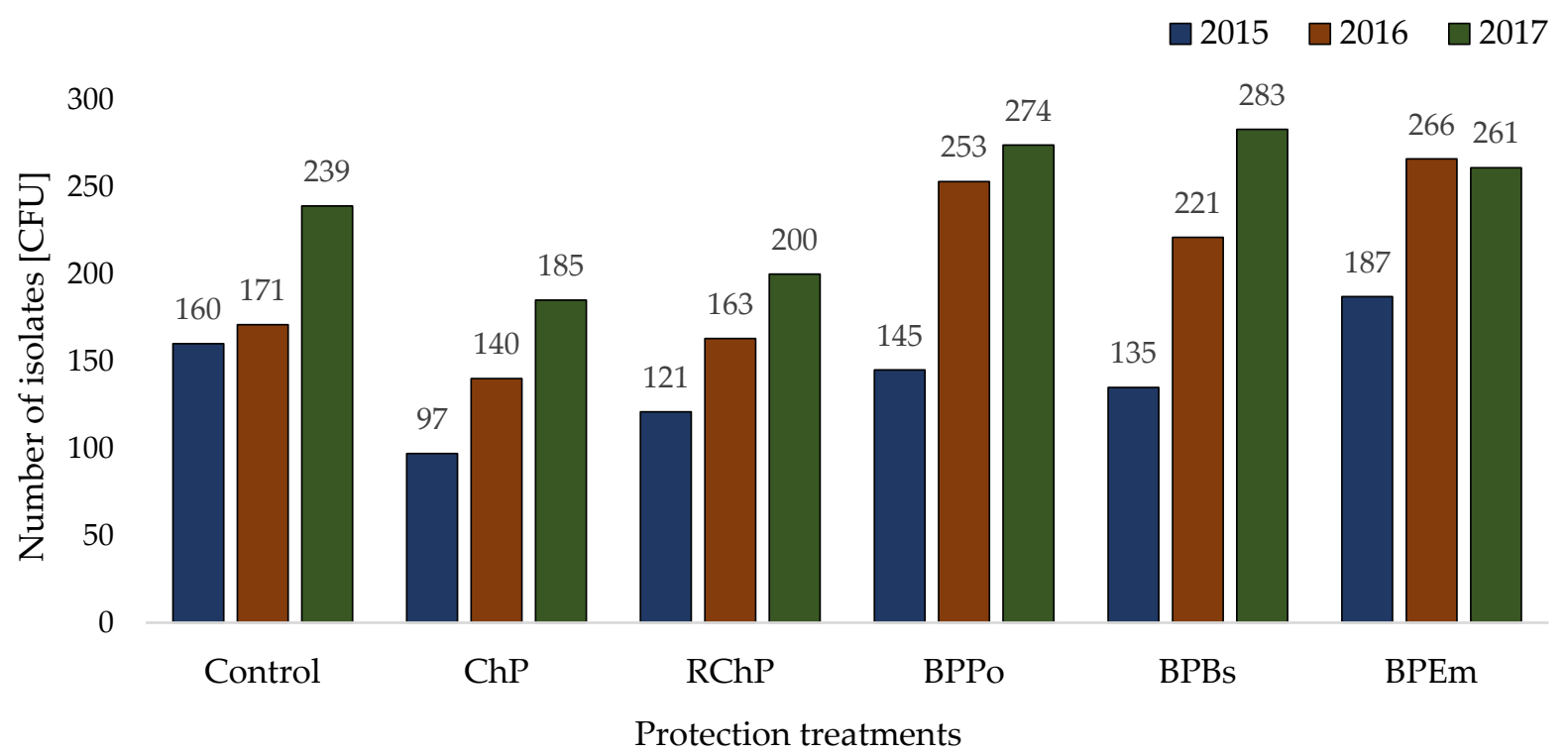

Figure 2. Number of colony forming units (CFUs) isolated from internally infected horseradish roots.

It was shown that in the plots where seedlings were treated with PGP (E. maxima) and BCA (P. oligandrum, B. subtilis), more CFUs were isolated from $5 \mathrm{~g}$ of roots that were showing the symptoms of the disease than in those treated with the ChP, RChP, or in the control group. At the same time, a significant correlation was found between CFU and the intensity of Verticillium wilt of horseradish roots from the plots where the seedlings were treated with P. oligandrum, B.subtilis, and thiophanate methyl before planting (Table 3). The data do not support the conclusion that there is a correlation between CFU and DSI in the plots where seedlings were treated with E. maxima extract and the control plot.

Table 3. Relationships between the intensity of Verticillium wilt of horseradish roots (DSI) and the number of colony forming units (CFUs) and between the intensity of Verticillium wilt of horseradish roots (DSI) and the sum of precipitation in the growing season (SP) and CFUs and the sum of precipitation in the growing season.

\begin{tabular}{|c|c|c|c|c|c|c|c|}
\hline \multirow{2}{*}{$\begin{array}{l}\text { Protection } \\
\text { Treatments }\end{array}$} & \multicolumn{3}{|c|}{$\hat{D S I}=b_{0}+b_{1} \cdot S P$} & \multicolumn{3}{|c|}{$\hat{D S I}=a_{0}+a_{1} \cdot C F U$} & \multirow{2}{*}{$r_{S P . C F U}$} \\
\hline & $\boldsymbol{b}_{0}$ & $b_{1}$ & $r_{D S I . S P}$ & $a_{0}$ & $a_{1}$ & $r_{\text {DSI.CFU }}$ & \\
\hline Control & 92.9 & $-0.345^{* * *}$ & $-0.984^{* * *}$ & 89.2 & $-0.274^{* * *}$ & $-0.851^{* * *}$ & $0.927^{* * *}$ \\
\hline ChP & 57.5 & $-0.073^{* * *}$ & $-0.935^{* * *}$ & 64.5 & $-0.307^{* * *}$ & $-0.934^{* * *}$ & $1.000^{* * *}$ \\
\hline $\mathrm{RChP}$ & 40.4 & $-0.040^{* * *}$ & $-0.976^{* * *}$ & 50.9 & $-0.187^{* * *}$ & $-0.984^{* * *}$ & $0.999 * * *$ \\
\hline ВРPo & 76.4 & $-0.101^{* * *}$ & $-0.895^{* * *}$ & 93.7 & $-0.302^{* * *}$ & $-0.996^{* * *}$ & $0.928 * * *$ \\
\hline BPBs & 79.3 & $-0.102^{* * *}$ & $-0.926^{* * *}$ & 84.9 & $-0.264^{* * *}$ & $-0.960 * * *$ & $0.995^{* * *}$ \\
\hline BPEm & 35.0 & $-0.024^{* *}$ & $-0.712^{* * *}$ & 30.0 & -0.029 & -0.205 & $0.830^{* * *}$ \\
\hline
\end{tabular}

$t$-test significant respectively at: $p<0.01^{* *} ; p<0.001^{* * *}$. Control - Without protection; ChP-Chemical protection; RChP-Reduced chemical protection with the participation of biopreparations and biostimulants; BPPo-Biological protection (root cuttings treatment before planting with Pythium oligandrum); BPBs—Biological protection (root cuttings treatment before planting with Bacillus subtilis); BPEm-Biological protection (root cuttings treatment before planting with Ecklonia maxima). 
For all protective treatments, the coefficients of the linear regression equations of the intensity of the DSI of Verticillium wilt of horseradish roots from the sum of atmospheric precipitation during the growing season (SP) are statistically significant (Table 3). As the amount of rainfall increases, the DSI value decreases. For the BPEm treatment, an increase in precipitation by $1 \mathrm{~mm}$ causes the smallest $(0.024 \mathrm{pp})$ reduction in the severity of this disease. In this combination, no statistically significant relationship was found between DSI Verticillium wilt of horseradish roots and CFUs. These relationships were statistically significant with respect to the remaining treatments. For ChP, an increase in CFU by one unit causes a DSI decrease of $0.307 \mathrm{pp}$. There was a significant positive correlation between the amount of precipitation during the growing season and CFUs.

3.2.2. Qualitative Analysis of Microorganisms Colonizing Horseradish Roots Affected by Verticillium Wilt

In the course of the pathogenesis of Verticillium wilt of horseradish root, the species composition, frequency, and biodiversity of the microorganisms involved are important. During the three-year study; 3508 isolates were isolated from horseradish roots with clear symptoms of the disease (Table 4).

Table 4. List of species of microorganisms isolated from horseradish roots affected by Verticillium wilt in the years $2015-2017$.

\begin{tabular}{|c|c|c|c|c|c|}
\hline Phylum & Genus & Species & $\begin{array}{l}\text { Number of } \\
\text { Isolates }\end{array}$ & $\begin{array}{c}\text { Isolation } \\
\text { Frequency } \mathrm{C}[\%]\end{array}$ & $\begin{array}{l}\text { Group of } \\
\text { Attendance }\end{array}$ \\
\hline \multirow{21}{*}{ Ascomycota } & Acremonium & A. strictum (W. Gams) & 9 & 0.26 & \multirow{3}{*}{ SR } \\
\hline & \multirow{2}{*}{ Aspergillus } & A. niger Tiegh. & 14 & 0.40 & \\
\hline & & A. terreus Thom & 12 & 0.34 & \\
\hline & \multirow{2}{*}{ Alternaria } & A. brassicae (Berk.) Sacc. & 188 & 5.36 & $\mathrm{D}$ \\
\hline & & A. alternata(Fr.) Keissel & 100 & 2.85 & \multirow{2}{*}{ SD } \\
\hline & Botrytis & B. cinerea Pers. & 73 & 2.08 & \\
\hline & Chaetomium & C. globosum Kunze ex Fr. & 41 & 1.17 & $\mathrm{R}$ \\
\hline & Clonostachys & $\begin{array}{l}\text { C. rosea (Link) Schroers, Samuels, Seifert \& } \\
\text { W. Gams }\end{array}$ & 10 & 0.28 & SR \\
\hline & Curvularia & C. lunata (Wakker) Boedijn & 63 & 1.79 & $\mathrm{R}$ \\
\hline & Colletotrichum & C. acutatum J.H. Simmonds & 86 & 2.45 & SD \\
\hline & Epicoccum & E. nigrum Link (2.93) & 195 & 5.56 & \multirow{2}{*}{$\mathrm{D}$} \\
\hline & \multirow{9}{*}{ Fusarium } & F. acuminatum Ellis \& Everh. & 229 & 6.53 & \\
\hline & & F. avenaceum (Fr.) Sacc. & 94 & 2.68 & SD \\
\hline & & F. culmorum (Wm.G. Sm.) Sacc. & 41 & 1.17 & $\mathrm{R}$ \\
\hline & & F. equiseti (Corda) Sacc. & 117 & 3.33 & \multirow{4}{*}{ SD } \\
\hline & & $\begin{array}{l}\text { F. proliferatum (Matsush.) Nirenberg ex } \\
\text { Gerlach \& Nirenberg }\end{array}$ & 139 & 3.96 & \\
\hline & & F. solani (Mart.) Sacc. & 114 & 3.25 & \\
\hline & & F. incarnatum (Desm.) Sacc. & 77 & 2.19 & \\
\hline & & F. sambucinum Fuckel & 51 & 1.45 & \multirow{2}{*}{$\mathrm{R}$} \\
\hline & & F. oxysporum Schltdl. & 39 & 1.11 & \\
\hline & Ilyonectria & $\begin{array}{l}\text { I. destructans (Zinssm.) Rossman, L. } \\
\text { Lombard \& Crous }\end{array}$ & 236 & 6.73 & $\mathrm{D}$ \\
\hline
\end{tabular}


Table 4. Cont

\begin{tabular}{|c|c|c|c|c|c|}
\hline Phylum & Genus & Species & $\begin{array}{l}\text { Number of } \\
\text { Isolates }\end{array}$ & $\begin{array}{c}\text { Isolation } \\
\text { Frequency C [\%] }\end{array}$ & $\begin{array}{l}\text { Group of } \\
\text { Attendance }\end{array}$ \\
\hline & \multirow{3}{*}{ Penicillium } & P. expansum Link & 90 & 2.56 & SD \\
\hline & & P. verrucosum Dierckx & 14 & 0.40 & \multirow{6}{*}{ SR } \\
\hline & & Penicillium spp. & 33 & 0.97 & \\
\hline & \multirow{3}{*}{ Phoma } & P. herbarum Westend. & 13 & 0.37 & \\
\hline & & $\begin{array}{c}\text { Didymella glomerata (Corda) Qian Chen \& L. } \\
\text { Cai (P. glomerata) }\end{array}$ & 21 & 0.60 & \\
\hline & & $\begin{array}{c}\text { Juxtiphoma eupyrena (Sacc.) Valenz.-Lopez, } \\
\text { Crous, Stchigel, Guarro \& J.F. Cano (P. } \\
\text { eupyrena) }\end{array}$ & 31 & 0.88 & \\
\hline & Ulocladium & U. consortiale (Thüm.) E.G.Simmons & 24 & 0.68 & \\
\hline & Sclerotinia & S. sclerotiorum (Lib.) de Bary & 91 & 2.60 & \multirow{2}{*}{ SD } \\
\hline & Trichoderma & T. viride Pers. ex Gray & 77 & 2.19 & \\
\hline & \multirow{2}{*}{ Verticillium } & V. albo-atrum Reinke \& Berthold & 56 & 1.60 & $\mathrm{R}$ \\
\hline & & V. dahliae Kleb. & 504 & 14.37 & $\mathrm{E}$ \\
\hline Basidiomycota & Rhizoctonia & R. solani Kühn & 237 & 6.75 & $\mathrm{D}$ \\
\hline \multirow{3}{*}{ Zygomycota } & Rhizopus & Rh. stolonifer (Ehrenb.) Vuill. & 38 & 1.09 & $\mathrm{R}$ \\
\hline & Rhizomucor & Rhizomucor spp. & 13 & 0.37 & \multirow{2}{*}{ SR } \\
\hline & Mucor & Mucor spp. & 19 & 0.54 & \\
\hline \multicolumn{3}{|r|}{ Total fungi } & 3189 & 90.91 & \\
\hline Oomycota & Globisporangium & $\begin{array}{l}\text { G. irregulare (Buisman) Uzuhashi, } \\
\text { Tojo \& Kakish }\end{array}$ & 241 & 6.87 & $\mathrm{D}$ \\
\hline \multicolumn{3}{|c|}{ Unknown microorganisms } & 78 & 2.22 & \\
\hline \multicolumn{3}{|r|}{ Total } & 3508 & 100 & \\
\hline
\end{tabular}

E—eudominants (>10\%); D—dominants (5.1-10.0\%); SD—subdominants (2.1-5.0\%); R-recedents (1.1-2.0\%); SR—subrecedents (<1\%).

Of these, $90.91 \%$, that is 3189 species, were fungi, and $6.87 \%$ were Globisporangium irregulare (241 isolates), which was the only representative of Oomycota. The isolated fungi belonged to 34 species and represented 21 genera within the clusters Ascomycota, Basidiomycota, and Zygomycota. At the same time, the 17 genera belonging to Ascomycota accounted for $82.16 \%$ of the total isolated fungi. Only one species- $V$. dahliae-was determined as eudominant, with a $14.37 \%$ share. The group of dominants, constituting a share of $37.80 \%$ of the total number of isolated microorganisms, included, in decreasing order (in terms of percentage), G. irregulare (6.87\%), R. solani (6.75\%), Ilyonectria destructans (syn. Cylindrocarpon destructans) (6.73\%), Fusarium acuminatum (6.53\%), Epicoccum nigrum (5.56\%), and A. brassicae (5.36\%). The subdominant group had a share of $28.06 \%$ and comprised 11 species, of which 6 belonged to the genus Fusarium: F. acuminatum-6.53\%, F. proliferatum-3.96\%, F. equiseti-3.33\%, F. solani-3.25\%, F. avenaceum $-2.68 \%$, F. incarnatum-2.19\%, A. alternate-2.85\%, Sclerotinia sclerotiorum-2.60\%, Penicillium expansum-2.56\%, and Colletotrichum acutatum-2.45\%. The complex nature of the etiological factors causing Verticillium wilt of horseradish roots means that they can be considered as an ecological micro-niche or "microhabitat", which is shaped by, inter alia, weather factors and plant protection measures. In assessing the biodiversity of these microhabitats, we have applied the basic criterion of biodiversity, which is species richness (S). It is obvious that this biodiversity is negligible compared to that found in soil. Nevertheless, it seems to be important in the pathogenesis of Verticillium wilt of horseradish roots.

In the analysed years, the smallest number (i.e., lowest richness) of species, namely 26, was recorded in the warmest season with the highest water deficit-i.e., in 2015 (Supplementary Table S1). On the other hand, in the years 2016-2017, along with the 
increase in recorded precipitation, the species richness increased to 37 (Table 5, Supplementary Table S2). The same number of species was obtained in the BPPo and BPMe plots. On the other hand, the species richness in the control plot was 25. With full chemical protection $(\mathrm{ChP})$, the $\mathrm{S}$ index equalled 19. In the studies to date, there are no reports from research studies that would involve the biodiversity assessment of the community of microorganisms associated with diseases of complex etiology. Earlier studies indicate that with the increasing biodiversity (expressed by various indicators), the severity of disease symptoms decreases [42].

Table 5. Frequency of species in microbial communities isolated from horseradish roots.

\begin{tabular}{|c|c|c|c|c|c|c|}
\hline \multirow{2}{*}{$\begin{array}{l}\text { Species of } \\
\text { Fungi }\end{array}$} & & \multicolumn{5}{|c|}{ Protection Treatments } \\
\hline & ChP & RChP & BPPo & BPBs & BPEm & Control \\
\hline A. brassicae & & 4.41 & 6.55 & 2.43 & 3.66 & 6.15 \\
\hline A. alternata & 2.14 & 4.61 & 1.77 & 0.81 & 0.76 & 4.37 \\
\hline B. cinerea & & 0.77 & 1.09 & 0.40 & 3.03 & 1.94 \\
\hline C. globosum & & 1.54 & 1.36 & 0.40 & 1.39 & \\
\hline C. lunata & 2.14 & 0.77 & 1.91 & 1.62 & 2.14 & 1.29 \\
\hline C. acutatum & & 2.88 & 1.77 & 1.21 & 1.89 & 3.07 \\
\hline E. nigrum & 3.57 & 0.96 & 8.73 & 12.55 & 8.07 & 1.94 \\
\hline F. acuminatum & 5.71 & 7.87 & 4.37 & 0.81 & 5.67 & 9.87 \\
\hline F. avenaceum & 3.57 & 4.41 & 0.95 & & 0.63 & 5.50 \\
\hline F. culmorum & 1.43 & 1.34 & 0.95 & & 0.88 & 1.29 \\
\hline F. equiseti & 3.57 & 3.26 & 3.14 & 3.64 & 2.65 & 4.21 \\
\hline F. proliferatum & 2.86 & 3.45 & 3.55 & 4.45 & 4.41 & 3.24 \\
\hline F. solani & 1.43 & 1.92 & 2.59 & 1.62 & 4.29 & 3.40 \\
\hline F. incarnatum & & 0.19 & 1.36 & 1.21 & 3.03 & 2.75 \\
\hline F. sambucinum & 3.57 & 1.34 & 1.91 & 1.21 & 0.76 & 1.46 \\
\hline F. oxysporum & & & 0.95 & 0.81 & 2.14 & 0.49 \\
\hline I. destructans & 10.01 & 8.64 & 6.55 & 9.31 & 8.95 & 3.56 \\
\hline P. expansum & 4.29 & 4.03 & 2.86 & 1.62 & 2.52 & 0.49 \\
\hline P. verrucosum & 2.14 & 0.58 & 0.41 & 0.81 & 0.38 & \\
\hline S. sclerotiorum & & 2.69 & 3.82 & 4.86 & 2.40 & 0.81 \\
\hline T. viride & & & 0.95 & 2.02 & 5.17 & 0.65 \\
\hline V. albo-atrum & 2.14 & 1.73 & 1.50 & 0.40 & 1.64 & 1.29 \\
\hline V. dahliae & 13.57 & 19.96 & 20.70 & 19.03 & 11.22 & 25.57 \\
\hline R. solani & 20.00 & 8.25 & 5.46 & 8.50 & 4.79 & 5.83 \\
\hline Rh. stolonifer & & 0.58 & 1.50 & 2.02 & 1.51 & \\
\hline Rhizomucor spp. & & & 0.95 & 2.43 & 0.13 & \\
\hline Mucor spp. & & & & & & \\
\hline Total fungi & 84.28 & 88.10 & 92.90 & 90.69 & 91.05 & 90.29 \\
\hline G. irregulare & 12.86 & 9.21 & 6.28 & 8.91 & 6.18 & 7.93 \\
\hline $\mathrm{S}$ & 19 & 29 & 37 & 32 & 37 & 25 \\
\hline Explanations & $\begin{array}{c}\text { Eudominants }(>10 \%) \\
\text { Subdominants }(2.1-5.0 \%) \\
\text { Subrecedents }(<1 \%)\end{array}$ & & & $\begin{array}{l}\text { Domina } \\
\text { Recede }\end{array}$ & $\begin{array}{l}1-10.0 \%) \\
1-2.0 \%)\end{array}$ & \\
\hline
\end{tabular}

In 2015, the eudominant group had the largest share (38.81\%), mainly due to the record-high frequency of $V$. dahliae (28.16\%), followed by the $10.65 \%$ share of $A$. Brassicae(Supplementary Table S1). The $V$. dahliae species was a constant component of the eudominant group in all of the studied years, and in 2016, it was its only representative, accounting for $19.23 \%$. In the last growing season, R. solani $(10.90 \%)$ and I. destructans $(10.16 \%)$ also belonged to the group of eudominants. On the other hand, the share of the dominant group ranged from $9.75 \%$ to $20.88 \%$, and F. acuminatum was the only representative of dominants in 2015 (9.75\%). Then, R. solani and I. destructans dominated in 2016. In turn, G. irregulare $(8.80 \%)$ and E. nigrum $(8.18 \%)$ dominated in the communities of fungi isolated in 2017. 
In all protection variants, $V$. dahliae belonged to the group of eudominants, isolated with the highest frequency from the infected roots of the control plot $(25.57 \%)$ (Table 5, Supplementary Table S2). This proves that the tested preparations limited the development of this species. Its lowest share, at the level of $11.22 \%$, was recorded among isolates obtained from the BPEm combination.

The dominant role of $V$. dahliae in the pathogenesis of Verticillium wilt is confirmed by other authors [28-30,32,61,62]. Moreover, in the complex of microorganisms causing Verticillium wilt of horseradish roots progressing from the vascular bundles, the following ranked as dominants: Globisporangium irregulare (Pythium irregulare), R. solani, Ilynonectria destructans (Cylindrocarpon destructans, Fusarium acuminatum, Epicocum nigrum and Alternaria brassicae). There is no information in the literature concerning the share of I. destructans and G. irregulare in the complex causing Verticillium wilt of horseradish roots. Numerous authors point to the high pathogenicity of I. destructans in relation to the underground parts of many plant species [63-67]. According to $\mathrm{Yu}$ [28], F. acuminatum is a constant component of the complex of Verticillium wilt of horseradish roots. Pathogens such as F. acuminatum, R. solani, and G. irregulare were most frequently isolated from the $\mathrm{ChP}$ plot. This proves chemical protection to be ineffective against these pathogens. In particular, $R$. solani exhibits exceptional resistance to synthetic fungicides [68,69]. In view of the above information, the use of BCAs and PGPs is revealed as an alternative method that can be used to reduce pathogens and disease severity without adversely affecting the environment. Brožova [70] claims that P. oligandrum not only reduces the concentration in soil of R. solani, Fusarium spp. and many other significant pathogens, but it also increases the population of antagonists. Ourstudydoes not supportthis conclusion. The antagonistic species of Trichoderma viride with the highest frequency was found in the community of fungi isolated from the infected horseradish roots of the BPEm plot (treated with E. maxima extract). This was also the observation of previously published studies [61,71]. Antagonism of fungi of the genus Trichoderma against $R$. solani has been observed repeatedly, and other mechanisms such as competition for food and induction of resistance genes have been pointed out [72-74]. In the present study, the increase in T. viride frequency was also accompanied by a smaller proportion of $R$. solani. Koutb and Ali [75] report that E. nigrum is an antagonist effective in reducing the pathogenic activity of $P$. irregulare. The same reaction was observed in our study. Infected roots from the combination of seedling treatment with B. subtilis and P. oligandrum as well as E. maxima were colonized by E. nigrum with the highest frequency, while the share of G. irregulare decreased.

Diversity of interactions between the dominant microrganisms colonizing horseradish roots with symptoms of Verticillium wilt of horseradish roots was demonstrated (Table 6). Eudominants $V$. dahliae significantly negatively correlated with $I$. destructans and $T$. viride. It was concluded that $I$. destructans had different microhabitat preferences than V.dahliae. The frequency of this fungus increased in the years with more rainfall, while the development of $V$. dahliae was favored by drought (Supplementary Table S1). It turned out that T. viride as an antagonist can significantly reduce the population of $V$. dahliae as well as G. irregulare and F. acuminatum. E. nigrum showed very strong antagonism towards F. avenaceum and F. acuminatum. The significantly positive strong correlation between $V$. dahliae and $A$. brassicae, as well as $R$. solani and G. irregulare, indicates the synergism of these pathogens in the Verticillium wilt of horseradish roots complex. 
Table 6. Correlations between microorganisms occurring with the highest frequency in the communities of microorganisms isolated from diseased horseradish roots.

\begin{tabular}{|c|c|c|c|c|c|c|c|c|}
\hline $\begin{array}{l}\text { Species of } \\
\text { Fungi }\end{array}$ & V. dahliae & $\begin{array}{c}\text { G. } \\
\text { irregulare }\end{array}$ & R. solani & $\begin{array}{c}\text { F. acumina- } \\
\text { tum }\end{array}$ & $\begin{array}{c}F . \\
\text { avenaceum }\end{array}$ & $\begin{array}{c}\text { A. } \\
\text { brassicae }\end{array}$ & $\begin{array}{c}\text { E. } \\
\text { nigrum }\end{array}$ & $\begin{array}{l}\text { I. destruc- } \\
\text { tans }\end{array}$ \\
\hline G. irregulare & -0.207 & & & & & & & \\
\hline R. solani & -0.383 & $0.948^{* * *}$ & & & & & & \\
\hline F. acuminatum & 0.341 & 0.033 & -0.066 & & & & & \\
\hline F. avenaceum & $0.468 *$ & 0.412 & 0.258 & $0.881^{* * *}$ & & & & \\
\hline A. brassicae & $0.674 * *$ & $-0.811^{* * *}$ & $-0.857^{* * *}$ & 0.375 & 0.128 & & & \\
\hline E. nigrum & -0.253 & -0.374 & -0.263 & $-0.909^{* * *}$ & $-0.948^{* * *}$ & -0.093 & & \\
\hline I. destructans & $-0.804^{* * *}$ & 0.457 & 0.535 * & $-0.583 *$ & -0.467 & $-0.805^{* * *}$ & 0.304 & \\
\hline T. viride & $-0.560 *$ & $-0.533 *$ & -0.453 & -0.288 & $-0.641^{* *}$ & 0.003 & 0.544 * & 0.201 \\
\hline
\end{tabular}

$t$-test significant respectively at $p<0.05^{*} ; p<0.01^{* *} ; p<0.001^{* * *}$.

\subsection{Chemical Composition of Horseradish Roots}

The abundance of nutrients in vegetables is the basic feature that determines the suitability of their edible parts for consumption. The chemical composition is a varietal feature and may vary significantly depending on the soil, climatic, and agro-technical conditions [76]. Vegetables and fruits are one of the basic groups of food products that provide the ingredients necessary for proper functioning of the human body. A very important indicator of the quality and nutritional value of vegetables is the dry matter content. Based on its quantity, it can be established whether the product is rich in nutrients or not [77]. In the tested horseradish roots, the average dry matter content was $28.0 \mathrm{~g} \cdot 100 \mathrm{~g}^{-1}$ (Table 7), and it ranged from 23.1 to $31.1 \mathrm{~g} \cdot 100 \mathrm{~g}^{-1}$. Similar values for the dry matter content of horseradish have also been reported by other authors [78-80].

Table 7. Effect of protection treatments and year of horseradish cultivation on dry matter content $\left[\mathrm{g} \cdot 100 \mathrm{~g}^{-1}\right]$.

\begin{tabular}{|c|c|c|c|c|}
\hline \multirow{2}{*}{ Protection Treatments } & \multicolumn{3}{|c|}{ Year } & \multirow{2}{*}{ Mean } \\
\hline & 2015 & 2016 & 2017 & \\
\hline $\mathrm{ChP}$ & $26.2^{\mathrm{C}} \pm 0.14$ & $26.8^{d} \pm 0.32$ & $23.1^{\mathrm{a}} \pm 0.36$ & $25.4 \pm 1.71$ \\
\hline $\mathrm{RChP}$ & $28.7^{\mathrm{gh}} \pm 0.41$ & $27.7^{\mathrm{e}} \pm 0.29$ & $24.5^{\mathrm{b}} \pm 0.41$ & $27.0 \pm 1.90$ \\
\hline ВPРо & $27.5^{\mathrm{e}} \pm 0.14$ & $31.8^{1} \pm 0.18$ & $28.2^{\mathrm{fg}} \pm 0.36$ & $29.2 \pm 1.98$ \\
\hline BPBs & $27.7^{\mathrm{e}} \pm 0.18$ & $28.9^{h} \pm 0.24$ & $28.1^{\mathrm{f}} \pm 0.18$ & $28.2 \pm 0.55$ \\
\hline BPEm & $31.3^{\mathrm{k}} \pm 0.18$ & $30.7^{\mathrm{j}} \pm 0.22$ & $27.6^{\mathrm{e}} \pm 0.18$ & $29.9 \pm 1.70$ \\
\hline Control & $30.1^{\mathrm{i}} \pm 0.18$ & $28.5^{g} \pm 0.12$ & $26.2^{\mathrm{c}} \pm 0.12$ & $28.3 \pm 1.67$ \\
\hline Mean & $28.6 \pm 1.01$ & $29.1 \pm 1.48$ & $26.3 \pm 1.86$ & $28.0 \pm 1.24$ \\
\hline
\end{tabular}

Values marked with the same letters do not differ statistically significantly, $p<0.05$.

The two-factor analysis of variance showed that the level of dry matter was statistically significantly different-both depending on the year of cultivation and the protection treatments applied. The lowest amount of dry matter was found in horseradish roots from PD plots-namely, $25.4 \mathrm{~g} \cdot 100 \mathrm{~g}^{-1}$ on average-while the highest amount was found in BPEm plots (29.9 g.100 g $\mathrm{g}^{-1}$ on average). Witkowicz et al. [51] reported that pre-sowing treatment of buckwheat seeds with E. maxima algae extract also favoured the accumulation of dry matter in the sprouts of this plant, while B. subtilis reduced the level of this component. Having analysed the level of dry matter in horseradish roots depending on the year of plant cultivation, we observed that the horseradish roots most abundant in dry matter were those grown in 2016, that is the year in which the hydrothermal conditions were the closest to the optimal horseradish requirements. In turn, the lowest level of dry matter was characteristic of the roots harvested in the year 2017, classified as moist and warm. Many researchers indicate large variability in the amount of dry matter in vegetables under the impact of climate and soil factors [81-84]. In turn, according to Marcinek and Hetman [85], the dry matter content in vegetables does not depend on the preparations 
used in plant cultivation. These hypotheses are confirmed in the studies of Wierzbicka and Majkowska [86] and Kowalska et al. [87].

In vegetable cultivation, apart from the yield, more and more attention is paid to the quality of the harvested crops, measured not only by such features as appearance and taste, but also by the content of organic ingredients [88]. Protein is one of the most important nutrients. Its content in the tested horseradish roots was in the range $14.8-21.6 \mathrm{~g} \cdot 100 \mathrm{~g}^{-1}$ dry matter (DM), which corresponds approx. $4-6 \mathrm{~g} \cdot 100 \mathrm{~g}^{-1}$ fresh weight (Table 8). The obtained results were similar to the data reported in the literature on the subject. According to Kunachowicz [78], the protein content in horseradish root is approx. $4.5 \mathrm{~g} \cdot 100 \mathrm{~g}^{-1}$, whereas Orłowski and Kołota [89] report a much lower value. On the other hand, Orłowski [90] determined 1.6-3.1 g of protein per $100 \mathrm{~g}$ of fresh root mass. On the basis of the conducted study, it was found that the tested horseradish roots contained more protein than other vegetables such as beets, carrots, cucumbers, parsley, and radishes and less than garlic and green peas [78]. As was observed in the case of dry matter, the content of protein in the roots was also significantly differentiated depending on the year of cultivation and protective treatments. Similar observations were also made by Noworodnik [91], who stated that the use of fungicides impacts the increase of the total protein content. The lowest protein content was found in horseradish roots obtained from the cultivation where BPPo was used, as well as those obtained in 2017. Significantly more of this nutrient was contained in horseradish roots in the BPEm and RChP plots.

Table 8. Effect of protection treatments and year of horseradish cultivation on protein content (g.100 $\mathrm{g}^{-1}$ dry matter).

\begin{tabular}{ccccc}
\hline \multirow{2}{*}{ Protection Treatments } & \multicolumn{3}{c}{ Year } & \multirow{2}{*}{ Mean } \\
\cline { 2 - 4 } & $\mathbf{2 0 1 5}$ & $\mathbf{2 0 1 6}$ & $\mathbf{2 0 1 7}$ & \\
\cline { 2 - 4 } ChP & $18.8^{\mathrm{j}} \pm 0.2$ & $17.2^{\mathrm{f}} \pm 0.03$ & $16.5^{\mathrm{d}} \pm 0.3$ & $17.5 \pm 1.05$ \\
RChP & $21.6^{\mathrm{n}} \pm 0.11$ & $20.6^{\mathrm{f}} \pm 0.07$ & $17.1^{\mathrm{f}} \pm 0.13$ & $19.8 \pm 2.03$ \\
BPPo & $18.5^{\mathrm{i}} \pm 0.05$ & $14.8^{\mathrm{a}} \pm 0.14$ & $16.9^{\mathrm{e}} \pm 0.10$ & $16.7 \pm 1.61$ \\
BPBs & $20.4^{\mathrm{l}} \pm 0.04$ & $18.1^{\mathrm{h}} \pm 0.07$ & $16.1^{\mathrm{c}} \pm 0.08$ & $18.2 \pm 1.84$ \\
BPEm & $21.4^{\mathrm{m}} \pm 0.17$ & $18.9^{\mathrm{j}} \pm 0.10$ & $16.9^{\mathrm{e}} \pm 0.06$ & $19.1 \pm 1.92$ \\
Control & $19.8^{\mathrm{k}} \pm 0.26$ & $17.5^{\mathrm{g}} \pm 0.05$ & $15.9^{\mathrm{b}} \pm 0.04$ & $17.7 \pm 1.69$ \\
Mean & $20.1^{ \pm} \pm 2.01$ & $17.8 \pm 2.14$ & $16.6 \pm 1.98$ & $18.2 \pm 1.94$ \\
\hline
\end{tabular}

Values marked with the same letters do not differ statistically significantly, $p<0.05$.

The fat content in horseradish roots was insignificant, and it did not exceed $1 \mathrm{~g}$ in $100 \mathrm{~g}$ of dry matter (Table 9). Based on the statistical analysis, it was found that the level of this component varied significantly depending on the plant protection method. The accumulation of fat in the roots was significantly favoured by the treatment of seedlings with the application of P. oligandrum.

Table 9. Effect of protection treatments and the year of horseradish cultivation on fat content ( $\mathrm{g} \cdot 100 \mathrm{~g}^{-1}$ dry matter).

\begin{tabular}{|c|c|c|c|c|}
\hline \multirow{2}{*}{ Protection Treatments } & \multicolumn{3}{|c|}{ Year } & \multirow{2}{*}{ Mean } \\
\hline & 2015 & 2016 & 2017 & \\
\hline $\mathrm{ChP}$ & $0.85^{\mathrm{cd}} \pm 0.02$ & $0.76^{b c} \pm 0.03$ & $0.69^{a} \pm 0.01$ & $0.77 \pm 0.07$ \\
\hline $\mathrm{RChP}$ & $0.96^{\mathrm{e}} \pm 0.01$ & $0.90^{\text {de }} \pm 0.02$ & $0.80^{b c} \pm 0.03$ & $0.89 \pm 0.07$ \\
\hline ВРPo & $1.05^{\mathrm{f}} \pm 0.13$ & $0.87^{\mathrm{d}} \pm 0.03$ & $0.82^{b c} \pm 0.02$ & $0.91 \pm 0.12$ \\
\hline BPBs & $0.89^{\text {de }} \pm 0.02$ & $0.72^{\mathrm{ab}} \pm 0.03$ & $0.70^{a b} \pm 0.02$ & $0.77 \pm 0.09$ \\
\hline BPEm & $0.79^{b c} \pm 0.01$ & $0.74^{\mathrm{abc}} \pm 0.03$ & $0.67^{\mathrm{a}} \pm 0.03$ & $0.73 \pm 0.06$ \\
\hline Control & $0.93^{\text {de }} \pm 0.03$ & 0.89 de \pm 0.02 & $0.75^{a b c} \pm 0.4$ & $0.86 \pm 0.09$ \\
\hline Mean & $0.91 \pm 0.09$ & $0.81 \pm 0.08$ & $0.74 \pm 0.08$ & $0.82 \pm 0.11$ \\
\hline
\end{tabular}

Values marked with the same letters do not differ statistically significantly, $p<0.05$. 
Carbohydrate turned out to be the basic component of root dry matter (Table 10). Significant differences in the level of this component were observed depending on both the year of cultivation and the protective treatments applied. The roots most abundant in these ingredients were those obtained in 2016 and those protected with the BPEm.

Table 10. Effect of protection treatments and year of horseradish cultivation on carbohydrate content (g.100 $\mathrm{g}^{-1}$ dry matter).

\begin{tabular}{ccccc}
\hline \multirow{2}{*}{ Protection Treatments } & \multicolumn{3}{c}{ Year } & Mean \\
\cline { 2 - 4 } & $\mathbf{2 0 1 5}$ & $\mathbf{2 0 1 6}$ & $\mathbf{2 0 1 7}$ & \\
\cline { 2 - 4 } ChP & $72.1^{\mathrm{g}} \pm 0.11$ & $69.1^{\mathrm{b}} \pm 0.15$ & $66.9^{\mathrm{a}} \pm 0.12$ & $69.3 \pm 2.22$ \\
RChP & $66.9^{\mathrm{a}} \pm 0.13$ & $69.5^{\mathrm{c}} \pm 0.04$ & $66.8^{\mathrm{a}} \pm 0.07$ & $69.5 \pm 2.24$ \\
BPPo & $72.8^{\mathrm{h}} \pm 0.07$ & $73.5^{\mathrm{j}} \pm 0.06$ & $70.7^{\mathrm{e}} \pm 0.11$ & $72.3 \pm 1.27$ \\
BPBs & $73.0^{\mathrm{i}} \pm 0.09$ & $73.8^{\mathrm{k}} \pm 0.04$ & $69.9^{\mathrm{d}} \pm 0.14$ & $72.3 \pm 1.75$ \\
BPEm & $75.8^{\mathrm{t}} \pm 0.03$ & $75.0^{\mathrm{l}} \pm 0.12$ & $71.0^{\mathrm{f}} \pm 0.15$ & $73.6 \pm 2.06$ \\
Control & $76.9^{\mathrm{m}} \pm 0.14$ & $72.1^{\mathrm{g}} \pm 0.06$ & $69.9^{\mathrm{d}} \pm 0.05$ & $72.9 \pm 3.06$ \\
Mean & $73.9 \pm 2.01$ & $72.0 \pm 1.56$ & $69.2 \pm 2.12$ & $71.7 \pm 2.68$ \\
\hline
\end{tabular}

Values marked with the same letters do not differ statistically significantly, $p<0.05$.

The ash content ranged from 6.21 to $7.89 \mathrm{~g} \cdot 100 \mathrm{~g}^{-1}$ dry matter (Table 11), which was approx. $2 \mathrm{~g} \cdot 100 \mathrm{~g}^{-1}$ fresh weight. The values obtained in the conducted studies were comparable to the values indicated in the tables of nutritional value [78]. A similar level of ash is also characteristic of "Hajdúsági torma" horseradish variety. The level of minerals expressed as ash was significantly differentiated depending on the protective treatments applied and the year of cultivation (Table 10). Higher values were characteristic for the roots obtained in 2016 and those from the control plot. The applied protection variants reduced the ash content. However, the roots from both the ChP and BPPo plots contained significantly less minerals. Literature lacks information on the impact of protection treatments on the chemical composition of horseradish, and such an impact is rarely analysed in relation to other vegetables. However, in studies on buckwheat, it was reported that pre-sowing treatment of seeds with P. oligandrum oospores reduces the ash level in sprouts [51].

Table 11. Effect of protection treatments and the year of horseradish cultivation on ash content ( $\cdot 100 \mathrm{~g}^{-1}$ dry matter).

\begin{tabular}{ccccc}
\hline \multirow{2}{*}{ Protection Treatments } & \multicolumn{3}{c}{ Year of Cultivation } & \multirow{2}{*}{ Mean } \\
\cline { 2 - 4 } & $\mathbf{2 0 1 5}$ & $\mathbf{2 0 1 6}$ & $\mathbf{2 0 1 7}$ & \\
\cline { 2 - 4 } ChP & $7.19^{\mathrm{g}} \pm 0.02$ & $7.09^{\mathrm{g}} \pm 0.03$ & $6.21^{\mathrm{a}} \pm 0.05$ & $6.83 \pm 0.46$ \\
RChP & $7.19^{\mathrm{g}} \pm 0.06$ & $7.35^{\mathrm{h}} \pm 0.05$ & $6.32^{\mathrm{b}} \pm 0.05$ & $6.95 \pm 0.48$ \\
BPPo & $6.46^{\mathrm{c}} \pm 0.03$ & $6.92^{\mathrm{f}} \pm 0.05$ & $6.68^{\mathrm{d}} \pm 0.12$ & $6.69 \pm 0.21$ \\
BPBs & $6.94^{\mathrm{f}} \pm 0.08$ & $6.81^{\mathrm{e}} \pm 0.02$ & $7.00^{\mathrm{fg}} \pm 0.07$ & $6.92 \pm 0.10$ \\
BPEm & $7.41^{\mathrm{h}} \pm 0.9$ & $8.01^{\mathrm{j}} \pm 0.01$ & $6.76^{\mathrm{de}} \pm 0.04$ & $7.39 \pm 0.54$ \\
Control & $7.32^{\mathrm{h}} \pm 0.04$ & $7.89^{\mathrm{i}} \pm 0.03$ & $7.02^{\mathrm{fg}} \pm 0.15$ & $7.41 \pm 0.39$ \\
Mean & $7.09 \pm 0.58$ & $7.35 \pm 1.02$ & $6.67 \pm 0.65$ & $7.03 \pm 0.47$ \\
\hline
\end{tabular}

Values marked with the same letters do not differ statistically significantly, $p<0.05$.

The alkalinity of ash in the tested horseradish roots ranged between 47.5 and $55.2 \mathrm{~cm}^{3}$ $0.1 \mathrm{M} \mathrm{HCl} \mathrm{g} \cdot 100 \mathrm{~g}^{-1}$ of dry matter (Table 12). There is no data available on this parameter in horseradish roots in the literature on the subject. Korus [92] investigated the alkalinity of ash in grass peaseeds, indicating much higher values, i.e., $85 \mathrm{~cm}^{3} 0.1 \mathrm{M} \mathrm{HCl} \cdot 100 \mathrm{~g}^{-1} \mathrm{DM}$. The statistical analysis of the obtained results showed statistically significant differences in the ash alkalinity depending on the applied treatments and the year of horseradish cultivation. The ash from BPPo-plot horseradish demonstrated the lowest alkalinity (on average, $\left.49.6 \mathrm{~cm}^{3} 0.1 \mathrm{M} \mathrm{HCl} \mathrm{g} \cdot 100 \mathrm{~g}^{-1} \mathrm{DM}\right)$, while the highest was found in the horseradish grown in the control plot $\left(53.2 \mathrm{~cm}^{3} 0.1 \mathrm{M} \mathrm{HCl}\right.$ per $\left.100 \mathrm{~g} \mathrm{DM}\right)$ (Table 11). A higher value 
of this parameter indicates a higher content of elements such as potassium, magnesium, sodium, and calcium, which are of high nutritional significance.

Table 12. Effect of protection treatments and the year of horseradish cultivation on ash alkalinity (0.1 $\mathrm{M} \mathrm{HCl}$ per $100 \mathrm{~g}$ of dry matter).

\begin{tabular}{ccccc}
\hline \multirow{2}{*}{ Protection Treatments } & \multicolumn{3}{c}{ Year of Cultivation } & \multirow{2}{*}{ Mean } \\
\cline { 2 - 4 } & $\mathbf{2 0 1 5}$ & $\mathbf{2 0 1 6}$ & $\mathbf{2 0 1 7}$ & \\
\cline { 2 - 4 } ChP & $50.1^{\mathrm{ef}} \pm 0.04$ & $51.9^{\mathrm{j}} \pm 0.06$ & $49.1^{\mathrm{d}} \pm 0.07$ & $50.4 \pm 1.21$ \\
RChP & $50.3^{\mathrm{g}} \pm 0.04$ & $52.5^{\mathrm{k}} \pm 0.03$ & $49.0^{\mathrm{cd}} \pm 0.04$ & $50.6 \pm 1.49$ \\
BPPo & $47.5^{\mathrm{a}} \pm 0.04$ & $51.0^{\mathrm{h}} \pm 0.09$ & $50.2^{\mathrm{fg}} \pm 0.16$ & $49.6 \pm 1.58$ \\
BPBs & $48.6^{\mathrm{b}} \pm 0.09$ & $51.2^{\mathrm{i}} \pm 0.12$ & $50.2^{\mathrm{f}} \pm 0.03$ & $50.0 \pm 1.13$ \\
BPEm & $50.1^{\mathrm{e}} \pm 0.07$ & $53.4^{1} \pm 0.03$ & $48.9^{\mathrm{c}} \pm 0.13$ & $50.8 \pm 2.00$ \\
Control & $53.5^{\mathrm{l}} \pm 0.05$ & $55.2^{\mathrm{f}} \pm 0.90$ & $51.0^{\mathrm{h}} \pm 0.12$ & $53.2 \pm 1.80$ \\
Mean & $50.0 \pm 2.09$ & $52.5 \pm 1.89$ & $49.7 \pm 1.38$ & $50.7 \pm 1.92$ \\
\hline
\end{tabular}

Values marked with the same letters do not differ statistically significantly, $p<0.05$.

\section{Conclusions}

The study showed that Verticillium wilt of horseradish roots, which determines the plant's suitability for food processing, is a serious problem in its cultivation. Especially in seasons with a high water deficit, where the DSI of roots reaches $52.00 \%$, a good opportunity to improve the health of plants is provided by the variant of biological protection using E. maxima for seedling treatment, as well as reduced chemical protection (RChP). On the other hand, biological protection with the participation of P. oligandrum and B.subtilis produces beneficial protective effects in vegetation seasons rich in rainfall and with optimal humidity. In the process leading to internal Verticillium wilt of horseradish roots, 34 species of fungi were identified as well as G. irregulare, the latter being the only recorded representative of Oomycetes. In the population of these microorganisms, depending on the protection applied, $V$. dahliae is eudominant with an incidence of $11.22 \%$ to $25.57 \%$. In turn, G. irregulare, I. destructans, F. acuminatum, R. solani, E. nigrum, and A. brassicae species were found consistently throughout the study, but their categorisation in the frequency groups depended on the growing season and protection measures used.The applied protection treatments differentiated quantitatively and qualitatively the communities of microorganisms isolated from the infected horseradish roots. A significant negative correlation was observed between the number of these communities (CFU) and the intensity of Verticillium wilt symptoms after the application of BPPo, BPBs, RChP, and ChP. The communities of microorganisms isolated from the diseased roots from the BPPo and BPEm plots were characterised by the greatest variety of species and the participation of antagonistic fungi. The content of dry matter, protein, fat, carbohydrates, and ash in horseradish roots as well as alkalinity are all significantly impacted by hydrothermal conditions in the given growing season. We also found statistically significant effects of the interaction between the cultivation years and plant protection treatments for each of the tested ingredients. Biological protection in years with sufficient water supply resulted in a significant increase in the content of dry matter, protein, and carbohydrates in horseradish roots. Under the influence of protective treatments, the ash content in the roots and the alkalinity of the ash were observed to have decreased.

Supplementary Materials: The following are available online at https:/ / www.mdpi.com/2076-341 7/11/2/680/s1, Table S1: Frequency of species in microbial communities isolated from horseradish roots in the years 2015-2017, Table S2: Frequency of species in microbial communities isolated from horseradish roots in depending of treatments protection. 
Author Contributions: Conceptualization, K.G.-K.; methodology, K.G.-K. and A.F.; software, K.G.-K., A.F.-F. and L.L.; validation, K.G.-K., E.B., A.F.-F. and A.F.; formal analysis, K.G.-K., L.L. and A.F., investigation, K.G.-K., E.B., L.L., A.F.-F. and A.F.; writing-original draft preparation, K.G.-K. and A.F.-F.; writing-review and editing, K.G.-K. and L.L.; visualization, K.G.-K.; supervision, E.B. All authors have read and agree to the published version of the manuscript.

Funding: This research was financed by the Ministry of Science and Higher Education of the Republic of Poland.

Institutional Review Board Statement: Not applicable.

Informed Consent Statement: Not applicable.

Data Availability Statement: Data sharing not applicable.

Acknowledgments: We express our gratitude to the staff of the Microbiological Diagnostics Laboratory of the Jagiellonian Center of Innovation for making fungi markings.

Conflicts of Interest: The authors declare no conflict of interest. The funders had no role in the design of the study; in the collection, analyses, or interpretation of data; in the writing of the manuscript; or in the decision to publish the results.

\section{References}

1. Johnston, J.S.; Pepper, A.E.; Hall, A.E.; Chen, Z.J.; Hodnett, G.; Drabek, J.; Lopez, R.; Price, H.J. Evolution of Genome Size in Brassicaceae. Ann. Bot. 2005, 95, 229-235. [CrossRef] [PubMed]

2. Walters, S.A.; Wahle, E.A. Horseradish Production in Illinois. Hort Technol. 2010, 20, 267-276. [CrossRef]

3. Bladh, K.W.; Olsson, K.M. Introduction and Use of Horseradish (Armoracia rusticana) as Food and Medicine from Antiquity to the Present: Emphasis on the Nordic Countries. J. Herbs Spices Med. Plants 2011, 17, 197-213. [CrossRef]

4. Bladh, K.W.; Liljeroth, E.; Poulsen, G.; Yndgaard, F.; Brantestam, A.K. Genetic diversity in Nordic horseradish, Armoracia rusticana, as revealed by AFLP markers. Genet. Resour. Crop. Evol. 2013, 61, 383-394. [CrossRef]

5. Shehata, A.; Mulwa, R.M.S.; Babadoost, M.; Uchanski, M.; Norton, M.A.; Skirvin, R.; Walters, S.A. Horseradish: Botany, Horticulture, Breeding. Hortic. Rev. 2009, 35, 221-261. [CrossRef]

6. Majewska, A.; Bałasińska, B.; Dąbrowska, B. Antioxidant properties of leaf and root extract and oil from different types of horseradish Armoracia rusticana. Folia Hort. 2004, 16, 15-22.

7. Kosson, R.; Horbowicz, M. Effect of Long Term Storage on Some Nutritive Components and Isothiocyanates Content in Roots of Two Horseradish Types. Veg. Crop. Res. Bull. 2008, 69, 155-164. [CrossRef]

8. Agneta, R.; Möllers, C.; Rivelli, A.R. Horseradish (Armoracia rusticana), a neglected medical and condiment species with a relevant glucosinolate profile: A review. Genet. Resour. Crop. Evol. 2013, 60, 1923-1943. [CrossRef]

9. Calabrone, L.; LaRocca, M.; Marzocco, S.; Martelli, G.; Rossano, R. Total Phenols and Flavonoids Content, Antioxidant Capacity and Lipase Inhibition of Root and Leaf Horseradish (Armoracia rusticana) Extracts. Food Nutr. Sci. 2015, 6, 64-74. [CrossRef]

10. Ciska, E.; Horbowicz, M.; Rogowska, M.; Kosson, R.; Drabińska, N.; Honke, J. Evaluation of Seasonal Variations in the Glucosinolate Content in Leaves and Roots of Four European Horseradish (Armoracia rusticana) Landraces. Pol. J. Food Nutr. Sci. 2017, 67, 301-308. [CrossRef]

11. Ar, R.; Lelario, F.; Agneta, R.; Möllers, C.; De Maria, S. Variation of glucosinolates concentration and root growth of horseradish as affected by nitrogen and sulphur supply. Plant Soil Environ. 2016, 62, 307-313. [CrossRef]

12. Bałasińska, B.; Nicolle, C.; Gueux, E.; Majewska, A.; Demigné, C.; Mazur, A. Dietary horseradish reduces plasma cholesterol in mice. Nutr. Res. 2005, 25, 937-945. [CrossRef]

13. Weil, M.J.; Zhang, Y.; Nair, M.G. Tumor Cell Proliferation and Cyclooxygenase Inhibitory Constituents in Horseradish (Armoracia rusticana) and Wasabi (Wasabia japonica). J. Agric. Food Chem. 2005, 53, 1440-1444. [CrossRef] [PubMed]

14. Wagner, A.E.; Boesch-Saadatmandi, C.; Dose, J.; Schultheiss, G.; Rimbach, G. Anti-inflammatory potential of allyl-isothiocyanaterole of Nrf2, NF-kB and microRNA-155. J. Cell. Mol. Med. 2012, 16, 836-843. [CrossRef] [PubMed]

15. Romeo, L.; Iori, R.; Rollin, P.; Bramanti, P.; Mazzon, E. Isothiocyanates: An Overview of Their Antimicrobial Activity against Human Infections. Molecules 2018, 23, 624. [CrossRef]

16. Azevedo, A.M.; Martins, V.C.; Prazeres, D.; Vojinović, V.; Cabral, J.M.; Fonseca, L.P. Horseradish peroxidase: A valuable tool in biotechnology. Biotechnol. Annu. Rev. 2003, 9, 199-247. [CrossRef]

17. Palanisamy, S.; Unnikrishnan, B.; Chen, S.M. An Amperometric Biosensor Based on Direct Immobilization of Horseradish Peroxidase on Electrochemically Reduced Graphene Oxide Modified Screen Printed Carbon Electrode. Int. J. Electrochem. Sci. 2012, 7, 7935-7947.

18. Spadiut, O.; Herwig, C. Production and purification of the multifunctional enzyme horseradish peroxidase. Pharm. Bioprocess. 2013, 1, 283-295. [CrossRef]

19. Gleń-Karolczyk, K. Fungi settling horseradish roots depending on the applied protection. J. Res. Appl. Agricult. Eng. 2015, $60,52-56$. 
20. Gleń, K. Evaluation of foliar fertilizers for horseradish (Armoracia rusticana Gaertn) against fungal diseases. Ecol. Chem. Eng. A 2008, 15, 331-336.

21. Gleń-Karolczk, K.; Boligłowa, E. The effect of Kelpak SL bioregulator on fungi isolated from the roots of horseradish (Armoracia rusticana Gaertn.). J. Res. Appl. Agricult. Eng. 2015, 60, 63-67.

22. Wedelsbäck Bladh, K. Biodiversity in Nordic Horseradish (Armoracia rusticana); Swedish University of Agricultural Sciences, Acta Universitatis Agriculturae Sueciae: Uppsala, Sweden, 2014; ISSN 1652-6880.

23. Verma, P.R.; Saharan, G.S.; Bartaria, A.M.; Shivpuri, A. Biological races of Albugocandida on Brassica juncea and Brassica rapa var.toria in India. J. Mycol. Plant Pathol. 1999, 29, 75-82.

24. Meena, P.D.; Verma, P.R.; Saharan, G.S.; Hossein Borhan, M. Historical perspectives of white rust caused by Albugo candida in oilseed brassica. J. Oilseed Brassica 2014, 5, 1-41.

25. Trkulja, N.; Milosavljević, A.; Mitrović, M.; Jović, J.; Toševski, I. First Report of Cercospora armoraciae, Causal Agent of Cercospora Leaf Spot, on Horseradish in Serbia. Plant Dis. 2015, 99, 1645. [CrossRef]

26. Dewage, C.S.K.; Klöppel, C.A.; Stotz, H.U.; Fitt, B.D.L. Host-pathogen interactions in relation to management of light leaf spot disease (caused by Pyrenopeziza brassicae) on Brassica species. Crop. Pasture Sci. 2018, 69, 9. [CrossRef]

27. Babadoost, M.; Wright, C.L.; Chen, W.; Bratsch, A.D. Horseradish research review. In Proceedings of the Horseradish Growers School, A surveillance of horseradish diseases in Illinois in 2000, Edwardsville, IL, USA, 25 January 2001.

28. Yu, J.M. Identification of Fungi and Bacteria Associated with Internally Discolored Horseradish Roots; University of Illinois at UrbanaChampaign: Urbana-Champaign, IL, USA, 2010; p. 96.

29. Mueller, J.P.; Percich, J.A.; Mitchell, J.E. Root deterioration associated with Verticillium wilt of horseradish. Plant Dis. 1982, 66, 410-414. [CrossRef]

30. Eastburn, D.M. Verticillium dahliae: A Causal Agent of Root Discoloration of Horseradish in Illinois. Plant Dis. 1994, 78, 496-498. [CrossRef]

31. Babadoost, M.; Bratsch, A.D.; Eastman, C.E.; Chen, W. Verticillium longisporum and Fusarium solani: Two new species in the complex of internal discoloration of horseradish roots. Plant Pathol. 2004, 53, 669-676. [CrossRef]

32. Yu, J.M.; Cafarov, I.H.; Babadoost, M. Morphology, Molecular Identity, and Pathogenicity of Verticillium dahliae and V. longisporum Associated with Internally Discolored Horseradish Roots. Plant Dis. 2016, 100, 749-757. [CrossRef]

33. Baćmaga, M.; Wyszkowska, J.; Kucharski, J. The effect of the Falcon 460 EC fungicide on soil microbial communities, enzyme activities and plant growth. Ecotoxicology 2016, 25, 1575-1587. [CrossRef]

34. Singh, Z.; Kaur, J.; Kaur, R.; Hundal, S.S. Toxic Effects of Organochlorine Pesticides: A Review. Am. J. Biosci. 2016, 4, 11. [CrossRef]

35. De Vries, F.T.; Thébault, E.; Liiri, M.; Birkhofer, K.; Tsiafouli, M.A.; Bjørnlund, L.; Jørgensen, H.B.; Brady, M.V.; Christensen, S.; De Ruiter, P.C.; et al. Soil food web properties explain ecosystem services across European land use systems. Proc. Natl. Acad. Sci. USA 2013, 110, 14296-14301. [CrossRef] [PubMed]

36. Wagg, C.; Bender, S.F.; Widmer, F.; Van Der Heijden, M. Soil biodiversity and soil community composition determine ecosystem multifunctionality. Proc. Natl. Acad. Sci. USA 2014, 111, 5266-5270. [CrossRef] [PubMed]

37. Bender, S.F.; Wagg, C.; Van Der Heijden, M. An Underground Revolution: Biodiversity and Soil Ecological Engineering for Agricultural Sustainability. Trends Ecol. Evol. 2016, 31, 440-452. [CrossRef]

38. Lori, M.; Symnaczik, S.; Mäder, P.; De Deyn, G.; Gattinger, A. Organic farming enhances soil microbial abundance and activity-A meta-analysis and meta-regression. PLoS ONE 2017, 12, e0180442. [CrossRef]

39. Rillig, M.C.; Lehmann, A.; Lehmann, J.; Camenzind, T.; Rauh, C. Soil Biodiversity Effects from Field to Fork. Trends Plant Sci. 2018, 23, 17-24. [CrossRef]

40. Meng, J.; Li, L.; Liu, H.; Li, Y.; Li, C.; Wu, G.; Yu, X.; Guo, L.; Cheng, D.; Muminov, M.A.; et al. Biodiversity management of organic orchard enhances both ecological and economic profitability. Peer J 2016, 4, e2137. [CrossRef]

41. Das, S.; Jeong, S.T.; Das, S.; Kim, P.J. Composted Cattle Manure Increases Microbial Activity and Soil Fertility More Than Composted Swine Manure in a Submerged Rice Paddy. Front. Microbiol. 2017, 8, 1702. [CrossRef]

42. Gleń-Karolczyk, K.; Boligłowa, E.; Antonkiewicz, J. Organic fertilization shapes the biodiversity of fungal communities associated with potato dry rot. Appl. Soil Ecol. 2018, 129, 43-51. [CrossRef]

43. Mierzwa-Hersztek, M.; Glen-Karolczyk, K.; Gondek, K. Fungistatic activity of composts with the addition of polymers obtained from thermoplastic corn starch and polyethylene-An innovative cleaner production alternative. Sci. Total. Environ. 2018, 635, 1063-1075. [CrossRef]

44. Khan, W.; Rayirath, U.P.; Subramanian, S.; Jithesh, M.N.; Rayorath, P.; Hodges, D.M.; Critchley, A.T.; Craigie, J.S.; Norrie, J.; Prithiviraj, B. Seaweed Extracts as Biostimulants of Plant Growth and Development. J. Plant Growth Regul. 2009, $28,386-399$. [CrossRef]

45. Thompson, B. Five years of Irish trials on biostimulants: The conversion of a skeptic. USDA For. Serv. Proc. 2004, 33, 72-79.

46. El-Shennawy, R.Z. Biological control of root-rot and wilt disease of faba bean using some bioagents. J. Plant Prot. Pathol. 2011, 2, 195-202. [CrossRef]

47. Benhamou, N.; Le Floch, G.; Vallance, J.; Gerbore, J.; Grizard, D.; Rey, P. Pythium oligandrum: An example of opportunistic success. Microbiology 2012, 158, 2679-2694. [CrossRef]

48. Khabbaz, S.E.; Abbasi, P.A. Isolation, characterization, and formulation of antagonistic bacteria for the management of seedlings damping-off and root rot disease of cucumber. Can. J. Microbiol. 2014, 60, 25-33. [CrossRef] 
49. Habtegebriel, B.; Boydom, A. Biocontrol of faba bean black root rot caused by Fusarium solani using seed dressing and soil application of Trichoderma harzianum. J. Biol. Control. 2017, 30, 169. [CrossRef]

50. Frederiks, C.; Wesseler, J.H. A comparison of the EU and US regulatory frameworks for the active substance registration of microbial biological control agents. Pest Manag. Sci. 2018, 75, 87-103. [CrossRef]

51. Witkowicz, R.; Biel, W.; Chlopicka, J.; Galanty, A.; Gleń-Karolczyk, K.; Skrzypek, E.; Krupa, M. Biostimulants and Microorganisms Boost the Nutritional Composition of Buckwheat (Fagopyrum esculentum Moench) Sprouts. Agronomy 2019, 9, 469. [CrossRef]

52. Witkowicz, R.; Biel, W.; Skrzypek, E.; Chłopicka, J.; Gleń-Karolczyk, K.; Krupa, M.; Prochownik, E.; Galanty, A. Microorganisms and Biostimulants Impact on the Antioxidant Activity of Buckwheat (Fagopyrum Esculentum Moench) Sprouts. Antioxidants 2020, 9, 584. [CrossRef]

53. Polish Soil Classification. Soil. Sci. Ann. 2011, 62, 1-193.

54. Świtoniak, M.; Kabała, C.; Charzyński, P. Proposal of English equivalents for the soil taxa names in the Polish Soils Classifica-tion. Soil. Sci. Ann. 2016, 67, 103-116. [CrossRef]

55. Wenzel, H. Zur erfassung des schadenausmasses in pflanzenschutz versuchen. Pflanzenschutz Ber. 1948, 15, 81-84.

56. De Carolis, E.; Posteraro, B.; Lass-Flörl, C.; Vella, A.; Florio, A.R.; Torelli, R.; Girmenia, C.; Colozza, C.; Tortorano, A.M.; Sanguinetti, M.; et al. Species identification of Aspergillus, Fusarium and Mucorales with direct surface analysis by matrixassisted laser desorption ionization time-of-flight mass spectrometry. Clin. Microbiol. Infect. 2012, 18, 475-484. [CrossRef] [PubMed]

57. Kunachowicz, H.; Czarnowska-Misztal, E.; Turlejska, H. Zasady żywienia człowieka. Wydawnictwo Szkolne Pedagogiczne SA Warszawa 2005, 5, 36-44. (In Polish)

58. Kasprzak, K.; Niedbała, W. Wskaźniki Biocenotyczne Stosowane Przy Porzadkowaniu i Analizie Danych w Badanych Ilościowych; Górny, M., Grüm, L., Eds.; PWN: Warszawa, Poland, 1981; p. 483. (In Polish)

59. Gardi, C.; Jeffery, S. Soil biodiversity. European Commission. Institute for Environmental and Sustainability. Luxemburg 2009, $10,2788-7831$.

60. Skowera, B. Zmiany warunków hydrotermicznych na obszarze Polski (1971-2010). Fragm. Agron. 2014, $31,74-87$.

61. Glen-Karolczk, K. Protective treatments shaping the yielding, healthiness and diversity of microorganisms associated with Verticillium wilt of horseradish roots (Armoracia rusticana Gaertn.). Zesz Nauk UR Krakowie 2019, 544, 136, (In Polish, English abstract).

62. Percich, J.A.; Johnson, D.R. A root rot complex of horseradish. Plant Dis. 1990, 74, 391-393. [CrossRef]

63. Rego, C.; Farropas, L.; Nascimento, T.; Cabral, A.; Oliveira, T. Black foot of grapevine: Sensitivity of Cylindrocarpon de-structans to fungicides. Phytopathol. Mediterr. 2006, 45, 93-100.

64. Kurzawińska, H. Fungi inhabiting the rhizosphere of persian cyclamen and their impact. Phytopathologia 2010, 57, 5-10.

65. Pastucha, A.; Kołodziej, B. The effect of irrigation and foliar fertilization on the colonization of american ginseng (Panax quinquefolium 1.) diseased parts by different micro-organisms. Acta Agrobot. 2012, 63, 179-188. [CrossRef]

66. Samad, J.; Nasimi, Z. First report of black-foot disease, caused by Cylindrocarpon destructans, on ornamental marigold (Tagetes minuta) in Iran. J. Plant Prot. Res. 2014, 54, 139-143. [CrossRef]

67. Farh, M.E.-A.; Kim, Y.-J.; Kim, Y.-J.; Yang, D.-C. Cylindrocarpon destructans/Ilyonectria radicicola -species complex: Causative agent of ginseng root-rot disease and rusty symptoms. J. Ginseng. Res. 2018, 42, 9-15. [CrossRef] [PubMed]

68. Reznikov, S.; Vellicce, G.R.; González, V.; De Lisi, V.; Castagnaro, A.P.; Ploper, L.D. Evaluation of chemical and biological seed treatments to control charcoal rot of soybean. J. Gen. Plant Pathol. 2016, 82, 273-280. [CrossRef]

69. Anderson, J.P.; Sperschneider, J.; Win, J.; Kidd, B.; Yoshida, K.; Hane, J.K.; Saunders, D.G.O.; Singh, K.B. Comparative secretome analysis of Rhizoctonia solani isolates with different host ranges reveals unique secretomes and cell death inducing effectors. Sci. Rep. 2017, 7, 10410. [CrossRef]

70. Brozova, J. Exploitation of the mycoparasitic fungus Pythium oligandrum in plant protection-A review. Plant Prot. Sci. 2012, 38, 29-35. [CrossRef]

71. Glen-Karolczyk, K. The effect of chitosan on yielding, health of the horseradish (Armoracia rusticana Gaertn.) roots and pathogenic fungi. J. Res. Appl. Agricult. Eng. 2016, 61, 113-118.

72. Heydari, A.; Pessarakli, M. A Review on Biological Control of Fungal Plant Pathogens Using Microbial Antagonists. J. Biol. Sci. 2010, 10, 273-290. [CrossRef]

73. Marroni, I.V.; Moura, A.B.; Ueno, B. Chemical and biological treatments of castor bean seeds: Effects on germination, emergence and associated microorganisms. Rev. Bras. Sement 2012, 34, 21-28. [CrossRef]

74. Mayo, S.; Gutiérrez, S.; Malmierca, M.G.; Lorenzana, A.; Campelo, M.P.; Hermosa, R.; Casquero, P.A. Influence of Rhizoctonia solani and Trichoderma spp. in growth of bean (Phaseolus vulgaris L.) and in the induction of plant defense-related genes. Front. Plant Sci. 2015, 6, 685. [CrossRef]

75. Koutb, M.; Ali, E.H. Potential of Epicoccum purpurascens Strain 5615 AUMC as a Biocontrol Agent of Pythium irregulare Root Rot in Three Leguminous Plants. Mycobiology 2010, 38, 286-294. [CrossRef] [PubMed]

76. Majkowska-Gadomska, J.; Dobrowolski, A.; Mikulewicz, E. Comparison of yield and nutrition some variety carrot (Daucus carota L.) Grown with ecological methods of protection. Zesz Probl. Post. Nauk Rol. 2016, 585, 121-129.

77. Filipiak-Florkiewicz, A. The effect of hydrothermal processing on selected health properties of cauliflower (Brassica oleracea var.botrytis L.). Zesz Nauk UR Krakowie 2011, 347, (In Polish, English abstract). 
78. Kunachowicz, A.; Przygoda, B.; Nadolna, I.; Iwanow, K. Tabele Składu i Wartości Odżywczej Żywności; Wydawnictwo Lekarskie: Warszawa, Poland, 2017. (In Polish)

79. Majewska, A.; Dabrowska, B.; Wẹglarz, Z. Yielding and content of nutrients and biologically active compounds in several ecotypes of horseradish (Armoracia rusticana Gaertn.) cultivated in different localities. Biul. Inst. Hod. Aklim. Roślin 2003, 226-227, 553-563.

80. Rivelli, A.R.; Caruso, M.C.; De Maria, S.; Galgano, F. Vitamin C content in leaves and roots of horseradish (Armoracia rusticana): Seasonal variation in fresh tissues and retention as affected by storage conditions. Emir. J. Food Agric. 2017, 29, 799-806. [CrossRef]

81. Adiku, S.; Renger, M.; Wessolek, G.; Facklam, M.; Hecht-Bucholtz, C. Simulation of the dry matter production and seed yield of common beans under varying soil water and salinity conditions. Agric. Water Manag. 2001, 47, 55-68. [CrossRef]

82. Gębczyński, P. Zmiany zawartości wybranych związków przeciwutleniających w mrożonych warzywach w zależności od obróbki wstępnej, warunków składowania i sposobu przygotowania do spożycia. Zesz Nauk AR Krakowie 2008, 445, 21-80, (In Polish, English abstract).

83. Kwabiah, B.W. Growth and yield of sweet corn (Zea mays L.) cultivars in response to planting date and plastic mulch in a short-season environmental. Sci. Hortic. 2004, 102, 147-166. [CrossRef]

84. Lisiewska, Z.; Korus, A.; Kmiecik, W.; Gęczyński, P. Effect of maturity stage on the content of ash components in raw and preserved grass pea (Lathyrus sativus L.) seeds. Int. J. Food Sci. Nutr. 2009, 57, 39-45. [CrossRef]

85. Marcinek, B.; Hetman, J. The effect of foliage feeding on the strucutre of yield, dry weight content and macroelements in the corms of Sparaxis tricolor Ker-Gawl. Acta Sci. Pol. Hortorum Cultus 2008, 7, 89-99.

86. Wierzbicka, B.; Majkowska, J. Wpływ nawożenia dolistnego na zawartość wybranych składników w korzeniach buraka ćwikłowego. Acta Agrophysica 2003, 85, 169-176, (In Polish, English abstract).

87. Kowalska, I.; Sady, W.; Szura, A. Effects of nitrogen form, foliar nutrition and growing place on yield and quality of lettuce. Acta Agrophysica 2006, 7, 619-631.

88. Biczak, R.; Herman, B.; Rychter, P. Effects of nitrogen, phosphorus and potassium fertilization on yield and biological value of leaf celery Part I: Vegetables yield and mineral composition. Proc. Ecopole 2011, 5, 161-171, (In Polish, English abstract).

89. Orłowski, M.; Kołota, E. Uprawa warzyw. Szczecin 1999, 274-278. (In Polish)

90. Orłowski, M. Polowa Uprawa Warzyw. Szczecin 2000, 370-377. (In Polish)

91. Noworodnik, K. Effect of some herbicides and fungicides on protein content and protein quality in grain of oats. Prog. Plant Post. Ochr. Roślin 2008, 48, 1535-1537.

92. Korus, A. Content of mineral components in fresh and preserved seeds of two grass pea (Lathyrus sativus L.) cultivars at the not fully mature stage. Acta Sci. Pol. Technol. Aliment. 2002, 1, 36-46. 